Key Words:

E-Area

Engineered Trench

B-25 Box

Retention:

Permanent

\title{
CORROSION AND POTENTIAL SUBSIDENCE SCENARIOS FOR BURIED B-25 WASTE CONTAINERS (U)
}

\author{
William E. Jones and Mark A. Phifer \\ Savannah River Technology Center
}

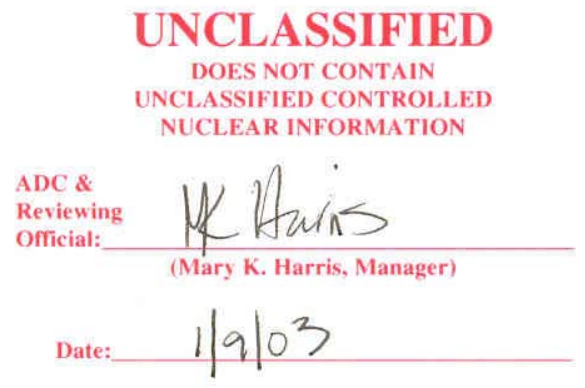

SEPTEMBER 2002

Westinghouse Savannah River Company

Savannah River Site

Aiken, SC 29808

Prepared for the U.S. Department of Energy Under

Contract Number DE-AC09-96SR18500 
This document was prepared in conjunction with work accomplished under Contract No. DE-AC09-96SR18500 with the U. S. Department of Energy.

\section{DISCLAIMER}

This report was prepared as an account of work sponsored by an agency of the United States Government. Neither the United States Government nor any agency thereof, nor any of their employees, makes any warranty, express or implied, or assumes any legal liability or responsibility for the accuracy, completeness, or usefulness of any information, apparatus, product or process disclosed, or represents that its use would not infringe privately owned rights. Reference herein to any specific commercial product, process or service by trade name, trademark, manufacturer, or otherwise does not necessarily constitute or imply its endorsement, recommendation, or favoring by the United States Government or any agency thereof. The views and opinions of authors expressed herein do not necessarily state or reflect those of the United States Government or any agency thereof.

This report has been reproduced directly from the best available copy.

Available for sale to the public, in paper, from: U.S. Department of Commerce, National Technical Information Service, 5285 Port Royal Road, Springfield, VA 22161, phone: (800) 553-6847, fax: (703) 605-6900

email: orders@ntis.fedworld.gov

online ordering: http://www.ntis.gov/help/index.asp

Available electronically at http://www.osti.gov/bridge

Available for a processing fee to U.S. Department of Energy and its contractors, in paper, from: U.S. Department of Energy, Office of Scientific and Technical Information, P.O. Box 62, Oak Ridge, TN 37831-0062,

phone: (865)576-8401,

fax: (865)576-5728

email: $\underline{\text { reports@ adonis.osti.gov }}$ 
Key Words:

E-Area

Engineered Trench

B-25 Box

Retention:

Permanent

\title{
CORROSION AND POTENTIAL SUBSIDENCE SCENARIOS FOR BURIED B-25 WASTE CONTAINERS (U)
}

\author{
William E. Jones and Mark A. Phifer \\ Savannah River Technology Center
}

SEPTEMBER 2002

Westinghouse Savannah River Company

Savannah River Site

Aiken, SC 29808

Prepared for the U.S. Department of Energy Under

Contract Number DE-AC09-96SR18500

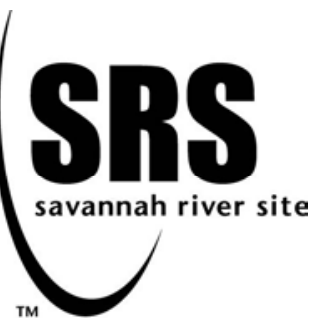


WSRC-TR-2002-00354

REVIEWS AND APPROVALS

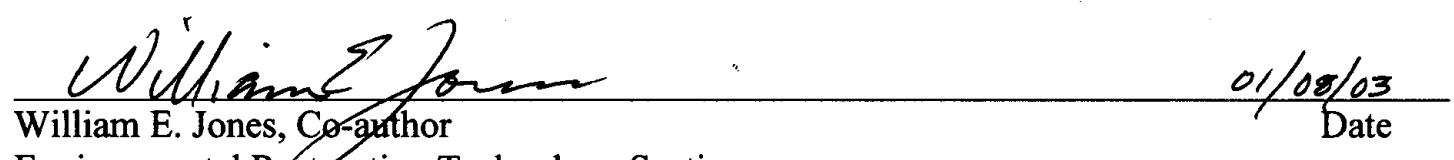

Environmental Restoration Technology Section

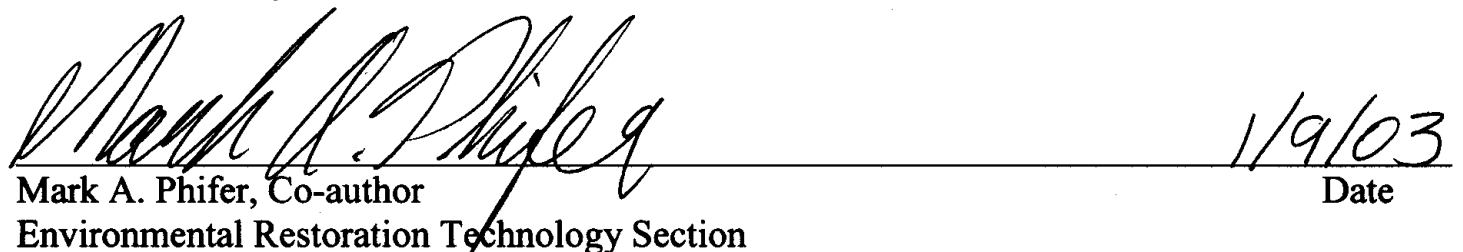

Environmental Restoration Technology Section

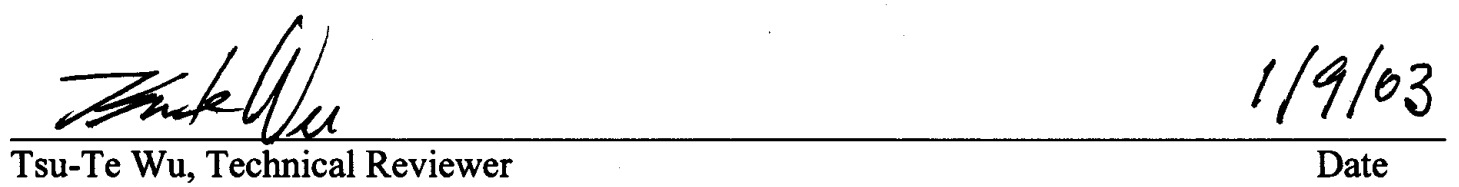

Engineering Modeling and Simulation Group,

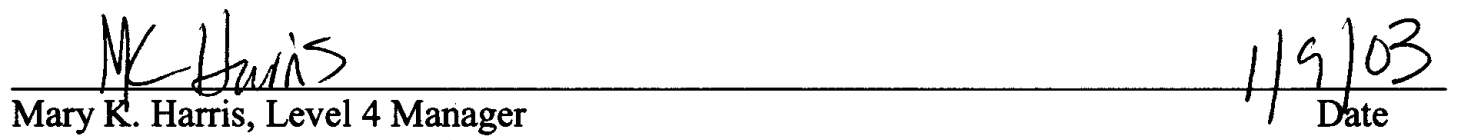

Environmental Restoration Technology Section

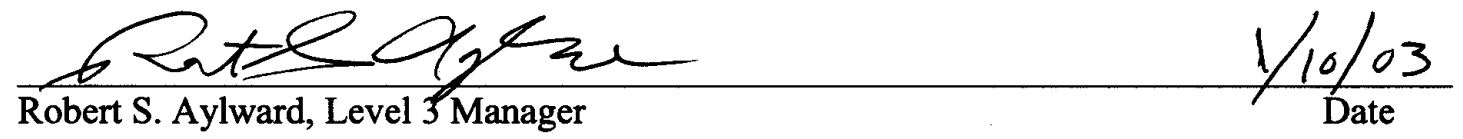

Environmental Restoration Technology Section

- ii - 


\section{TABLE OF CONTENTS}

LIST OF FIGURES .................................................................................................................. iv

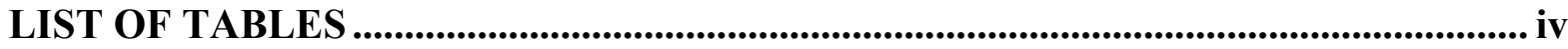

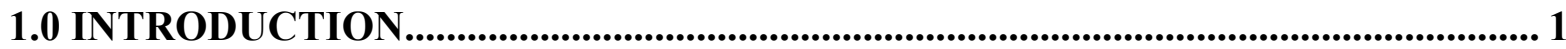

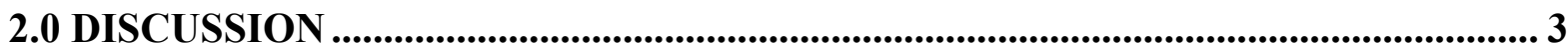

2.1 STATIC LOADING SCENARIOS ................................................................... 3

2.2 CONCEPTUAL MODEL .................................................................................................. 6

2.3 CORROSION RATE MEASUREMENT ....................................................................... 7

3.0 ESTIMATING STEEL-VOLUME LOSS OVER TIME ..........................................9

3.1 CONSTANT VOLUME METHOD..................................................................... 9

3.2 CONTINUOUS INCIPIENT AREA METHOD ............................................................ 11

3.3 SLOWING CORROSION METHOD .............................................................................. 12

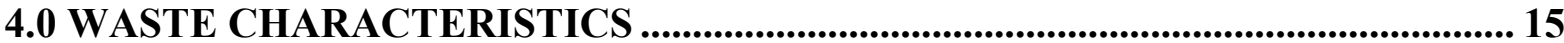

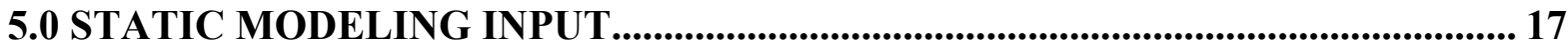

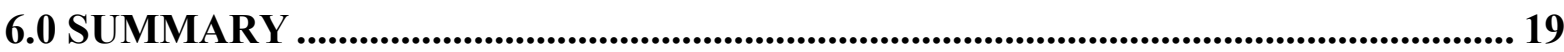

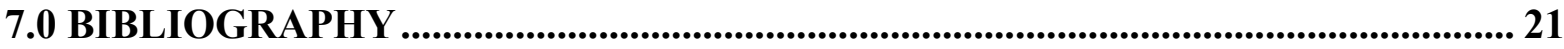

APPENDIX A - STEEL-VOLUME LOSS ESTIMATES................................................. 23 


\section{LIST OF FIGURES}

Figure 1. Subsidence Conceptual Model 7

Figure 2. Estimated percent B-25 steel-volume loss with time (constant volume method) . 10 Figure 3. Estimated percent B-25 steel-volume loss with time (continuous incipient area

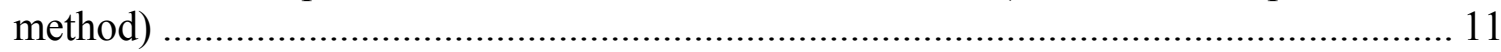

Figure 4. Estimated percent B-25 steel-volume loss with time (slowing corrosion method) 14

\section{LIST OF TABLES}

Table 1. Interim Cover and Kaolin Cap Soil Loading ........................................................ 4

Table 2. Interim Cover, Temporary Cap, Static Surcharge, and Kaolin Cap Soil Loading .. 5

Table 3. Summary Table (data from Dunn, 2002) ............................................................. 8

Table 4. B-25 Thickness for Static Modeling (from Constant Volume Method)................. 17

Table 5. B-25 Thickness for Static Modeling (from Continuous Incipient Area Method)... 17

Table 6. B-25 Thickness for Static Modeling (from Slowing Corrosion Method)............... 18 


\subsection{INTRODU CTION}

This report describes various scenarios to be modeled for static loading of B-25 containers in Engineered Trench \#1 (ET) at the Department of Energy's (DOE's) Savannah River Site in Aiken, South Carolina. Scenario information includes the static load to be used, estimated B-25 steel-volume loss with time due to corrosion, and waste characteristics.

The term "steel-volume loss" used herein refers to loss of original steel, not total volumeloss. Steel corrosion products may produce a net volume increase compared to the original steel volume, as Nozaki, et al. (2001) have pointed out. But corrosion products are assumed to contribute no structural strength. The values identified here for percent corrosion will be translated in structural finite element modeling to a remaining thickness of the B-25 wall, lid, or bottom (i.e., strength). Therefore, the term steel-volume loss is used.

The three steel-volume loss estimation methods are based on corrosion rates observed in an actual B-25 container buried near ET for eight years (Dunn, 2002), using best professional judgement. Projecting corrosion rates observed over a relatively short time forward over a much longer time into the future necessitates accepting some uncertainty. Kerry Dunn, who performed the B-25 corrosion study in 2001, has discussed the steel volume-loss-over-time issue with corrosion experts within SRTC and performed a literature search for relevant information. She has verified that the approaches taken here are reasonable, and the estimates derived by these approaches are within the boundaries indicated by her research.

"The literature on coupled chemical-mechanical processes in waste disposal systems is extremely sparse." (Nozaki et al., 2001). In fact, Nozaki, et al. (2001) is one of the few studies similar to this one. They evaluate glass and stainless steel corrosion in the arid environment of DOE's Hanford Site in Washington State. Their assumed stainless steel corrosion rates are on the order of 0.039 to 0.0039 mils per year (mpy). These arid, stainless steel corrosion rates seem to correspond reasonably with the more rapid, humid environment, low-carbon steel corrosion rates of 2.6 to 0.63 mpy observed in Dunn (2002). 
This page intentionally left blank.

Page 2 of 36 


\subsection{DISCUSSI ON}

\subsection{STATIC LO ADING SCENARIOS}

Two static loading scenarios will be modeled. The modeling objective is to identify subsidence resulting from static loads over the stacked B-25 boxes and the "thinning" (i.e., steel-volume/structural strength loss due to corrosion) of the B-25 lids, bottoms, and sides. Various B-25 steel thicknesses will be selected from the volume-loss vs. time curves derived from the Dunn (2002) corrosion study. The results will be used to estimate the amount of subsidence that might be expected at a given time following burial.

The first scenario involves placement of a 4 to 6 -ft thick interim soil cover over the Engineered Trench for 25 years, followed by construction of the kaolin cap outlined in the closure plan (Cook, et al., 2000). Load values to be used for the interim soil cover and kaolin cap scenario are presented in Table 1.

The second scenario involves the following four stages:

1) Placement of a 4 to 6-foot thick interim soil cover over the Engineered Trench for 25 years.

2) Followed by construction of a temporary cap. The temporary cap will remain in place until a static surcharge on the trench (i.e. placement of a temporary, 25-feet-thick soil layer on the trench) can effectively produce consolidation of the B-25s and their contents.

3) When static surcharging can effectively produce consolidation, the temporary cap will be removed and the static surcharge will be placed on the trench for approximately 3 to 6 months.

4) After static surcharging is complete, the surcharge will be removed and the kaolin cap outlined in the closure plan will be constructed.

The objective of this scenario is to estimate the time (after burial) at which static surcharge might be expected to effectively consolidate the B- 25 contents. Additionally, various surcharge thicknesses other than 25 feet can be evaluated to estimate the minimal necessary thickness. Load values to be used for the static surcharge scenario are presented in Table 2. 
Table 1. Interim Cover and Kaolin Cap Soil Loading

\begin{tabular}{|c|c|c|c|c|c|c|}
\hline Layer $^{1}$ & $\begin{array}{l}\text { Average } \\
\text { Thickness } \\
\text { (ft) }\end{array}$ & $\begin{array}{l}\text { Dry Bulk } \\
\text { Density, } \rho_{\mathrm{b}} \\
\left(\mathrm{psf}-\mathrm{g} / \mathrm{cm}^{3}\right)\end{array}$ & $\begin{array}{l}\text { Volumetric } \\
\text { Moisture } \\
\text { Content, } \theta^{7} \\
(\mathrm{~V} / \mathrm{V})\end{array}$ & $\begin{array}{l}\text { Gravimetric } \\
\text { Moisture } \\
\text { Content, } \omega^{9} \\
\left(\mathrm{M}_{\mathrm{w}} / \mathrm{M}_{\mathrm{s}}\right)\end{array}$ & $\begin{array}{l}\text { Wet Bulk } \\
\text { Density }{ }^{10} \\
\text { (psf) }\end{array}$ & $\begin{array}{l}\text { Load }^{11} \\
\text { (psf) }\end{array}$ \\
\hline \multicolumn{7}{|c|}{ Interim Soil Cover for 25 years } \\
\hline Interim Soil Cover & $6^{2}$ & $90-1.44^{2}$ & $0.2400^{8}$ & 0.167 & 105.0 & 630 \\
\hline \multicolumn{6}{|r|}{ Total } & 630 \\
\hline \multicolumn{7}{|c|}{ Total Load on B-25 Lid $=23.00 \mathrm{sq} \mathrm{ft} \times 630 \mathrm{psf}=14,490 \mathrm{lbs}$} \\
\hline \multicolumn{7}{|c|}{ Kaolin Cap after 25 years } \\
\hline Topsoil & 0.5 & $90-1.44^{3}$ & 0.2743 & 0.190 & 107.1 & 53.55 \\
\hline Backfill & 2.5 & $104-1.664^{4}$ & 0.2984 & 0.179 & 122.6 & 306.5 \\
\hline Geotextile Fabric & - & - & - & - & - & - \\
\hline Gravel & 1.0 & $105-1.68^{5}$ & 0.2124 & 0.126 & 118.2 & 118.2 \\
\hline Clay & 2.5 & $92.6-1.4816^{6}$ & 0.5600 & 0.378 & 127.6 & 319.0 \\
\hline Backfill & 3 & $104-1.664^{4}$ & 0.2400 & 0.144 & 119.0 & 357 \\
\hline Interim Soil Cover & $6^{2}$ & $90-1.44^{2}$ & $0.2400^{8}$ & 0.167 & 105.0 & 630 \\
\hline \multicolumn{6}{|r|}{ Total } & $1,784.25$ \\
\hline
\end{tabular}

Table 1. References:

${ }^{1}$ Cook et al. (2000) and McDowell-Boyer et al. (2000)

${ }^{2}$ Phifer and Wilhite (2001)

${ }^{3}$ The dry bulk density of the topsoil was taken as the same as that of the interim soil cover

${ }^{4}$ Johnson and Jensen (2001)

${ }^{5}$ Glover (2001)

${ }^{6}$ Phifer (1991)

${ }^{7}$ WSRC-TR-2002-00236, draft

${ }^{8}$ The volumetric moisture content of the interim soil cover has been taken as the same as that of the backfill immediately above it.

${ }^{9} \omega(\%)=\left(\left(\theta \times \rho_{\mathrm{w}}\right) / \rho_{\mathrm{b}}\right) \times 100$ where $\rho_{\mathrm{w}}=1 \mathrm{~g} / \mathrm{cm}^{3}$ (the density of water)

${ }^{10}$ Wet bulk density $=(1+\omega) \times \rho_{\mathrm{b}}$

${ }^{11}$ Load $=$ Wet Bulk Density $\times$ Average Thickness 
Table 2. Interim Cover, Temporary Cap, Static Surcharge, and Kaolin Cap Soil Loading

\begin{tabular}{|c|c|c|c|c|c|c|}
\hline Layer $^{1}$ & $\begin{array}{l}\text { Average } \\
\text { Thickness }{ }^{1} \\
\text { (ft) }\end{array}$ & $\begin{array}{l}\text { Dry Bulk } \\
\text { Density, } \rho_{\mathrm{b}} \\
\left(\mathrm{psf}-\mathrm{g} / \mathrm{cm}^{3}\right)\end{array}$ & $\begin{array}{l}\text { Volumetric } \\
\text { Moisture } \\
\text { Content, } \theta^{7} \\
(\mathrm{~V} / \mathrm{V}) \\
\end{array}$ & $\begin{array}{l}\text { Gravimetric } \\
\text { Moisture } \\
\text { Content, } \omega^{10} \\
\left(\mathrm{M}_{\mathrm{w}} / \mathrm{M}_{\mathrm{s}}\right)\end{array}$ & $\begin{array}{l}\text { Wet Bulk } \\
\text { Density }{ }^{11} \\
\text { (psf) }\end{array}$ & $\begin{array}{l}\text { Load }^{12} \\
\text { (psf) }\end{array}$ \\
\hline \multicolumn{7}{|c|}{ Interim Soil Cover for 25 years } \\
\hline Interim Soil Cover & $6^{2}$ & $90-1.44^{2}$ & $0.2400^{8}$ & 0.167 & 105.0 & 630 \\
\hline \multirow{2}{*}{\multicolumn{7}{|c|}{ Total Load on B-25 Lid $=23.00 \mathrm{sq} \mathrm{ft} \times 630 \mathrm{psf}=14,490 \mathrm{lbs}$. }} \\
\hline & & & & & & \\
\hline \multicolumn{7}{|c|}{ Temporary Cap after 25 years } \\
\hline Topsoil & 0.5 & $90-1.44^{3}$ & 0.2743 & 0.190 & 107.1 & 53.55 \\
\hline Backfill & 0.5 & $104-1.664^{4}$ & 0.2984 & 0.179 & 122.6 & 61.3 \\
\hline $\begin{array}{l}\text { Geosynthetic Clay } \\
\text { Liner }\end{array}$ & NA & NA & NA & NA & NA & $0.84^{13}$ \\
\hline Backfill & 1 & $104-1.664^{4}$ & 0.2984 & 0.179 & 122.6 & 122.6 \\
\hline Interim Soil Cover & $6^{2}$ & $90-1.44^{2}$ & $0.2400^{8}$ & 0.167 & 105.0 & 630 \\
\hline \multicolumn{6}{|c|}{ 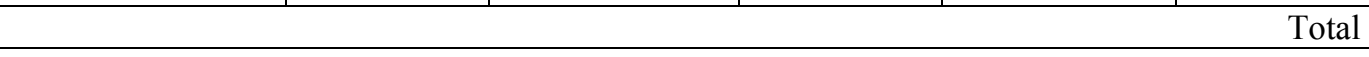 } & 868.29 \\
\hline \multicolumn{7}{|c|}{ Total Load on B-25 Lid $=23.00 \mathrm{sq} \mathrm{ft} \times 868.29 \mathrm{psf}=19,971 \mathrm{lbs}$} \\
\hline \multicolumn{7}{|c|}{ Static Surcharge for 3 to 6 Months } \\
\hline Static Surcharge & 25 & $90-1.44^{3}$ & $0.2743^{9}$ & 0.190 & 107.1 & 2677.5 \\
\hline Interim Soil Cover & $6^{2}$ & $90-1.44^{2}$ & $0.2400^{8}$ & 0.167 & 105.0 & 630 \\
\hline \multicolumn{6}{|r|}{ Total } & 3307.5 \\
\hline \multicolumn{7}{|c|}{ Total Load on B-25 Lid $=23.00 \mathrm{sq} \mathrm{ft} \times 3307.5 \mathrm{psf}=76,072 \mathrm{lbs}$} \\
\hline \multicolumn{7}{|c|}{ Kaolin Cap after Static Surcharging } \\
\hline Topsoil & 0.5 & $90-1.44^{3}$ & 0.2743 & 0.190 & 107.1 & 53.55 \\
\hline Backfill & 2.5 & $104-1.664^{4}$ & 0.2984 & 0.179 & 122.6 & 306.5 \\
\hline Geotextile Fabric & - & - & - & - & - & - \\
\hline Gravel & 1.0 & $105-1.68^{5}$ & 0.2124 & 0.126 & 118.2 & 118.2 \\
\hline Clay & 2.5 & $92.6-1.4816^{6}$ & 0.5600 & 0.378 & 127.6 & 319.0 \\
\hline Backfill & 3 & $104-1.664^{4}$ & 0.2400 & 0.144 & 119.0 & 357 \\
\hline Interim Soil Cover & $6^{2}$ & $90-1.44^{2}$ & $0.2400^{8}$ & 0.167 & 105.0 & 630 \\
\hline \multicolumn{6}{|r|}{ Total } & $1,784.25$ \\
\hline
\end{tabular}

Table 2. References:

${ }^{1}$ Layers and thicknesses for the interim soil cover and kaolin cap are from Cook, et al. (2000) and McDowell-Boyer, et al. (2000)

${ }^{2}$ Phifer and Wilhite (2001)

${ }^{3}$ The dry bulk density of the topsoil and static surcharge was taken as the same as that of the interim soil cover.

${ }^{4}$ Johnson and Jensen (2001)

${ }^{5}$ Glover (2001)

${ }^{6}$ Phifer (1991)

${ }^{7}$ WSRC-TR-2002-00236, draft 
Table 2. References - continued

${ }^{8}$ The volumetric moisture content of the interim soil cover for all configurations has been taken from the kaolin cap configuration and it has been assigned the same moisture content as that of the backfill immediately above it.

${ }^{9}$ The volumetric moisture content of the static surcharge has been assigned the same moisture content as that of the top soil.

${ }^{10} \omega=\left(\left(\theta \times \rho_{\mathrm{w}}\right) / \rho_{\mathrm{b}}\right)$ where $\rho_{\mathrm{w}}=1 \mathrm{~g} / \mathrm{cm}^{3}$ (the density of water)

${ }^{11}$ Wet bulk density $=(1+\omega) \times \rho_{\mathrm{b}}$

${ }^{12}$ Load $=$ Wet Bulk Density $\times$ Average Thickness

${ }^{13}$ GSE product data sheet for Bentofix ${ }^{\circledR}$ NSL at http://www.gseworld.com/global/United States/Products/Bentodix/Index.htm

\subsection{CONCEPTU AL MODEL}

The current modeling assumes that each B-25 lid in the uppermost layer of B-25s will be pushed down into its respective container by approximately $1.5 \mathrm{ft}$ due to soil loading and heavy equipment activities prior to dynamic compaction or static surcharge. (See waste strength characteristics section.) The area above each pushed-down lid contains soil that has forced the lid into its respective B-25. It is assumed that B-25 lids will remain in place for the underlying three layers of B-25s, and will degrade in the same manner as that observed in the corrosion study.

The B-25s containers are known to have from 10 percent to 90 percent void space (Phifer and Wilhite, 2001). Modeling requires that a single void space percentage be selected, therefore, the mid-point of the 10 percent to 90 percent range (50 percent waste material $/ 50$ percent void space) will be used. A variety of materials are disposed in the B-25 containers (from cloth to steel), with a known average uncompacted density of $178.5 \mathrm{~kg} / \mathrm{m}^{3}$ (Phifer and Wilhite, 2001). Modeling requires specific material strength values, therefore the waste characteristics used by Gong (2001) will be used. Out of a total height of $17.3 \mathrm{ft}$., the subsidence potential of a stack of four uncompacted B-25s after interim soil placement is $13.6 \mathrm{ft}$ (Phifer and Wilhite, 2001). This suggests a possible 79 percent long-term reduction in waste and container height, compared to the original waste and container height of $17.3 \mathrm{ft}$.

A B-25 stack degradation conceptual model is presented in Figure 1. The diagram shows the lid of the uppermost B-25 being pushed into the B-25 by the time the 4 to 6 -ft interim soil cover and overlying kaolin closure cap are constructed. Subsequent to the pittingbreakthrough period for the fork-lift-abraded zones located between the risers on the B-25 bottoms, waste and accumulated water begin moving downward through these opened areas onto the underlying B-25. As corrosion progresses, the waste material and underlying B-25 lid begin moving down into the underlying B-25. Downward movement of the interim soil layer/kaolin closure cap material eventually results in irregular surface subsidence and eventually compromises the cap's surface water infiltration control. 


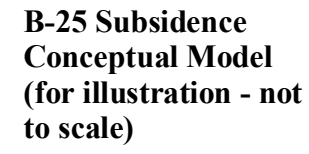

Side-view of Stack of B-25 Containers Prior to Soil Cover and Cap

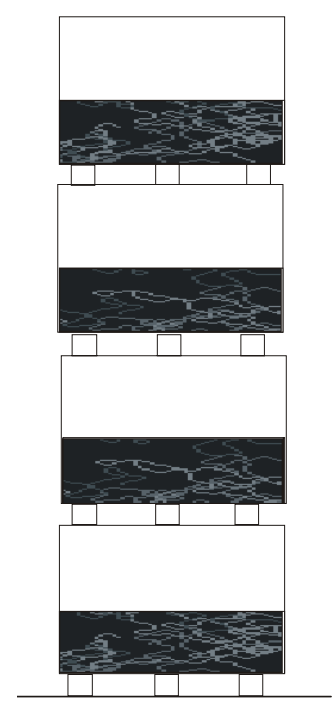

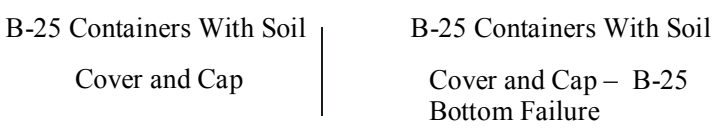
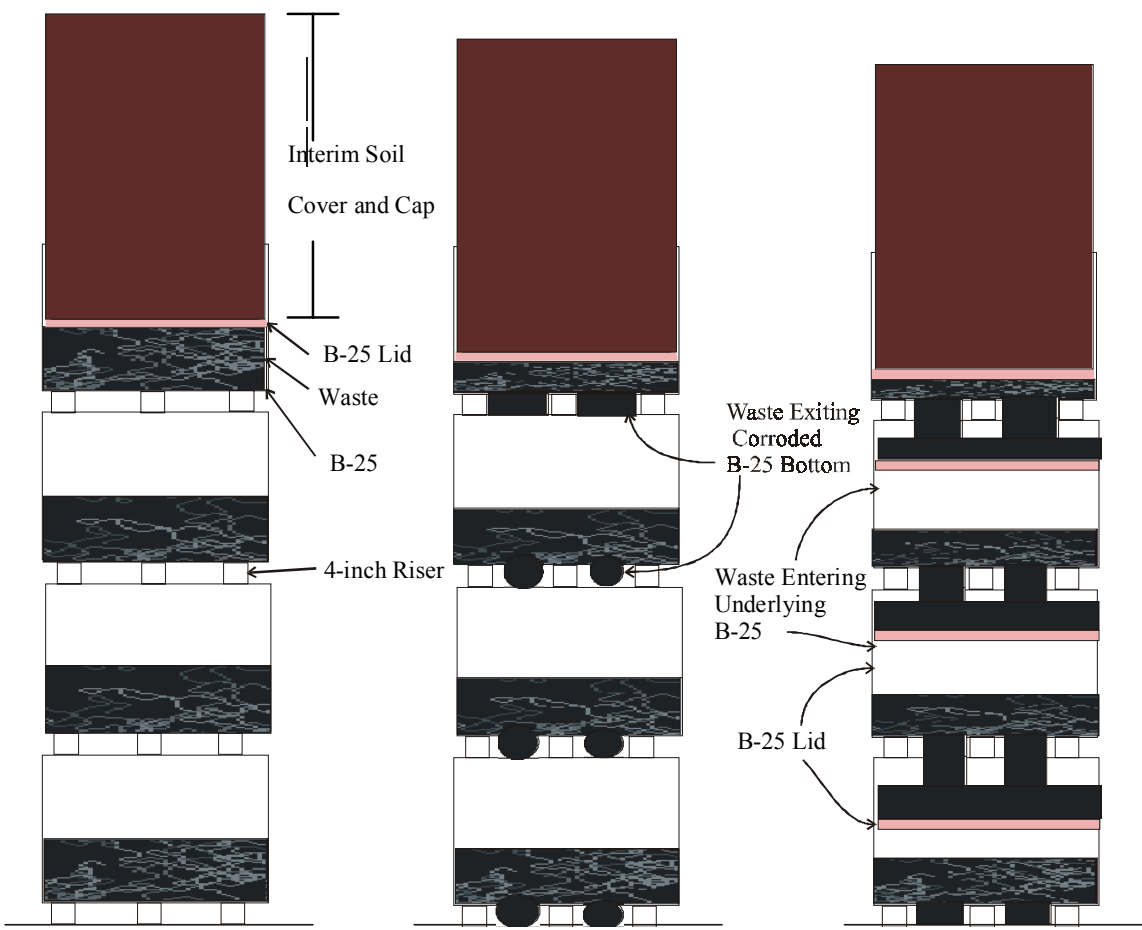

Figure 1. Subsidence Conceptual Model

\subsection{CORROSION RATE MEASUREMENT}

Dunn (2002) describes corrosion rates observed in a B-25 that had been buried for 8 years near the ET. The following is a summary of the B-25 lid, bottom, and sides corrosion observations and rates from Dunn (2002). Table 3 provides a summary of the Dunn (2002) corrosion rate data.

\section{B-25 Lid}

Two percent of the lid area was comprised of coalesced pitting with a corrosion rate of 2.4 mils per year (mpy). For a 14-gauge B-25 this would result in a reduction of 25 percent of the lid thickness in 8 years over this 2 percent of the lid area, and through-lid corrosion in 33 years. For a 12-gauge B-25, through-lid corrosion for this 2 percent of lid area will occur in about 46 years. The total lid area is $23.00 \mathrm{ft}^{2}\left(2.1 \mathrm{~m}^{2}\right)$. About 20 percent of the remaining lid area was comprised of scattered pitting, with a corrosion rate of $1.7 \mathrm{mpy}$, resulting in through-lid corrosion for a 14-gauge B-25 in about 46 years. Through-lid corrosion for this area for a 12-gauge B-25 will occur in about 64 years. 14 gauge steel is 0.075 inch thick, and 12 gauge is 0.1094 inch thick. 


\section{B-25 Bottom}

The total bottom area is $23.00 \mathrm{ft}^{2}\left(2.1 \mathrm{~m}^{2}\right)$. Twenty-four percent of the bottom area (forklift abraded areas located between risers on the B-25 bottom) has a corrosion rate of 2.6 mpy (through-bottom in 30 years for 14 gauge and 42 years for 12 gauge). The remaining 76 percent of the bottom has a corrosion rate of $0.63 \mathrm{mpy}$, yielding a 6 percent reduction in wall thickness in 8 years, and through-bottom corrosion in 125 years for a 14-gauge B-25 (174 years for 12-gauge).

\section{B-25 Sides}

Scattered pitting of the B-25 sides was observed at a 1.3 mpy rate that cover about 20 percent of the surface area. This resulted in about a 13 percent reduction in thickness for a 14-gauge B-25 after 8 years burial, with through-wall penetration in about 61 years $(84$ years for 12 gauge). The total area for all four sides is $77.02 \mathrm{ft}^{2}\left(7.2 \mathrm{~m}^{2}\right)$.

Table 3. Summary Table (data from Dunn, 2002)

\begin{tabular}{|l|l|l|l|l|l|l|l|}
\hline \multicolumn{1}{|c|}{$\begin{array}{c}\text { Part of } \\
\text { B-25 }\end{array}$} & \multicolumn{1}{|c|}{$\begin{array}{c}\text { Corrosion } \\
\text { Type }\end{array}$} & $\begin{array}{c}\text { Area of } \\
\text { B-25 } \\
\text { Part } \\
(\mathrm{sq} \mathrm{ft})\end{array}$ & $\begin{array}{c}\text { 12-gauge } \\
\text { Thickness } \\
(\mathrm{ft})\end{array}$ & $\begin{array}{c}\text { Area of } \\
\text { Corrosion } \\
(\%)\end{array}$ & $\begin{array}{c}\text { Corrosion } \\
\text { Rate } \\
(\mathrm{mils} / \mathrm{yr})\end{array}$ & $\begin{array}{c}\text { Corrosion } \\
\text { Rate } \\
(\mathrm{ft} / \mathrm{yr})\end{array}$ & $\begin{array}{c}\text { Through } \\
\text { Wall } \\
\text { Corrosion } \\
(\mathrm{yr})\end{array}$ \\
\hline Sides & Scattered Pitting & 77 & 0.0091 & 20 & 1.3 & 0.000108 & 84.2 \\
\hline Lid & Coalesced Pitting & 23 & 0.0091 & 2 & 2.4 & 0.000200 & 45.6 \\
\hline & Scattered Pitting & 23 & 0.0091 & 20 & 1.7 & 0.000142 & 64.4 \\
\hline Bottom & Forklift General & 23 & 0.0091 & 24 & 2.6 & 0.000217 & 42.1 \\
\hline & Inside General & 23 & 0.0091 & 76 & 0.63 & 0.000053 & 173.7 \\
\hline
\end{tabular}




\subsection{ESTIMATING STEEL-VOLUME LOSS OVER TIME}

Corrosion rates can increase with time, remain constant over time (i.e., be linear), or decrease with time depending upon the specific conditions present. Since the data utilized to predict the future corrosion represents only one data point obtained at 8 years post-burial, it is not known whether the corrosion rate is increasing, constant, or decreasing over time. Therefore three methods have been used to estimate 12-gauge B-25 steel-volume loss over time for the lid, bottom, and sides in order to represent all possible corrosion rate scenarios. Each method is based on corrosion types and rates observed in one B-25 that was buried near the ET for eight years (Dunn, 2002). Because the best information available comprises a single study of a single B-25 for a system with numerous variables (different container and waste types, different initial states of corrosion, etc.) the corrosion rate estimates should be expected to provide very general predictions. The three methods used are thought to represent the range of possible corrosion scenarios, from the most aggressive (very conservative approach) to less aggressive (but reasonable, based on corrosion behavior principles).

\subsection{CONSTANT VOLUME METHOD}

The first method assumes that the corrosion rates observed by Dunn (2002) continue in a straight-line fashion until 100 percent of the steel is corroded. This method essentially represents the constant corrosion rate over time (i.e., linear). The B-25 lid, bottom, and sides are evaluated separately, due to the different corrosion types and rates. For each type of corrosion (coalesced pitting, general pitting, corrosion in the forklift tine abraded areas, and/or general corrosion) the area (sq.ft.) observed to be impacted in Dunn (2002) is converted to volume (cu.ft.) impacted by multiplying the area impacted by the B-25 thickness (ft.). The volume impacted is divided by the number of years for through-wall penetration. This yields a volume-loss rate (cu.ft/yr). At a given year since disposal, the volume loss for each type of corrosion can then be calculated and added together to yield total volume reduction (cu.ft.).

\section{Lid Corrosion Rates}

For the B-25 lid, corrosion begins with both coalesced pitting (through-wall penetration in 46 years) and scattered pitting (through-wall penetration in 64 years). This method assumes that the volume loss for the first 46 years is the volume-loss due to coalesced pitting plus volume-loss due to scattered pitting. After 46 years, when the area of coalesced pitting is completely corroded, coalesced pitting is no longer considered, and the rate of volume loss is assumed to be at the scattered pitting rate, continuing unchanged until 100 percent of the lid has corroded (314 years). 


\section{Bottom Corrosion Rates}

It is assumed that all B-25 bottoms are affected by forklift abrasion and all degrade at the same rate as observed in the corrosion study. For the B-25 bottom, corrosion begins at a rapid rate (through-wall penetration in 42 years) occurring in the area between the risers that is abraded by forklift tines during B-25 handling, and with a much slower rate (through-wall penetration in 174 years) occurring over the remainder of the bottom. After 42 years, the corrosion in the abraded area is assumed to be complete. From this point, the rate of volume loss is assumed to be at the general corrosion rate and to occur uniformly across the entire remaining B-25 bottom, continuing unchanged until 100 percent of the bottom has corroded (174 years).

\section{Side Corrosion Rates}

For the B-25 sides, corrosion occurs by scattered pitting only. Through-wall penetration occurs in 84 years, continuing unchanged until 100 percent of the sides are corroded (420 years). All three of the volume-loss estimation methods described herein assume the corrosion rate of all B-25 sides is relatively uniform through time.

Volume-loss versus time estimates produced using the first method are provided in Figure 2. Table A-1 in Appendix A contains data and additional explanations for the volume-loss curves in Figure 2.

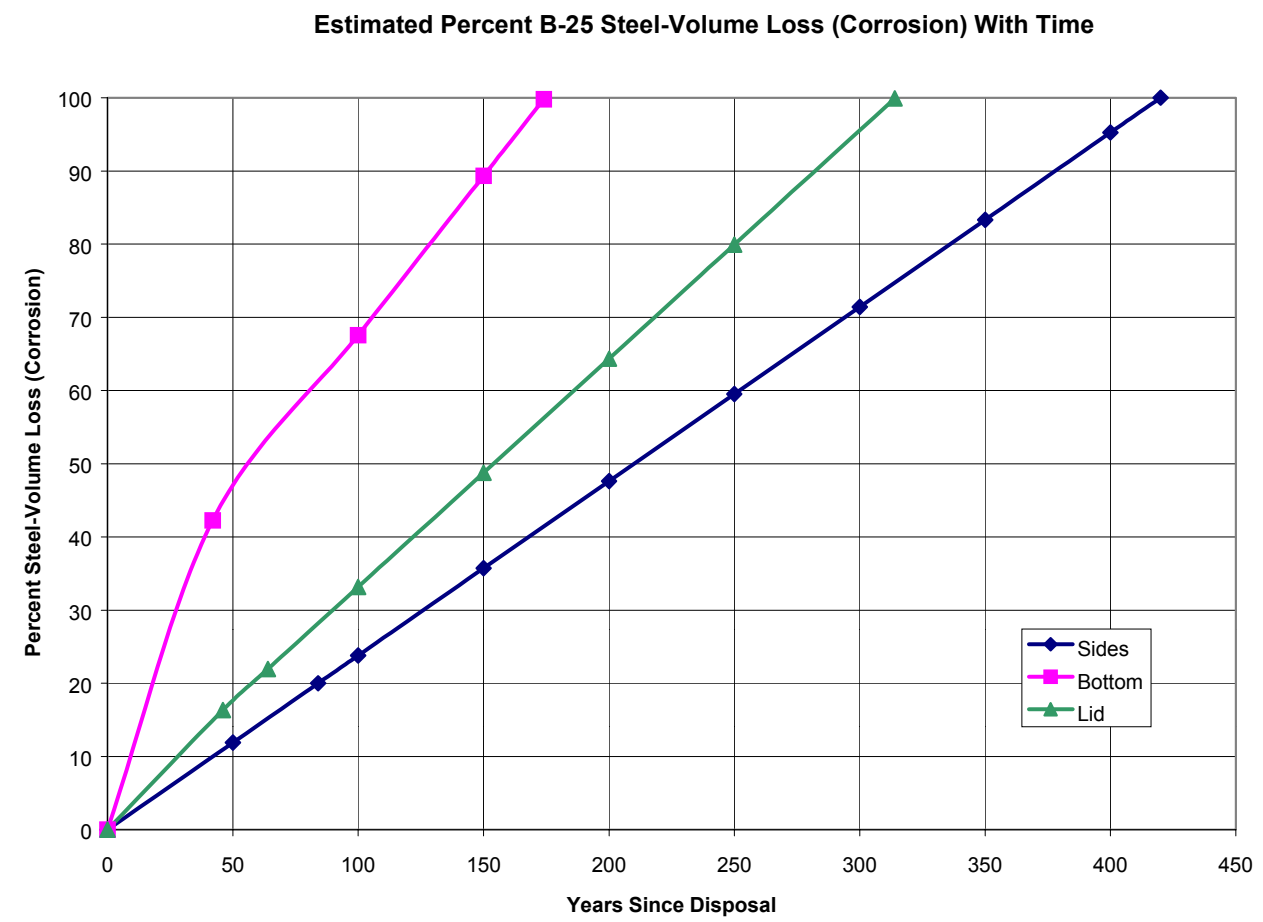

Figure 2. Estimated percent B-25 steel-volume loss with time (constant volume method) 


\subsection{CONTINUO US INCIPIENT AREA METHOD}

The continuous incipient area method essentially represents increasing corrosion over time. The following assumptions are made for the continuous incipient area method:

- Corrosion is initiated on a fixed percentage of the area each year for each applicable type of corrosion.

- Once corrosion is initiated on an area, the initial type of corrosion continues until that area is completely corroded away.

- The corrosion rates remain constant over time, and are based upon rates determined by Dunn (2002).

Volume-loss versus time estimates by the continuous incipient area method are provided in Figure 3. Table A-2 in Appendix A contains the data and explanations for the volume-loss curves in Figure 3.

Estimated Percent B-25 Steel-Volume Loss (Corrosion) With Time

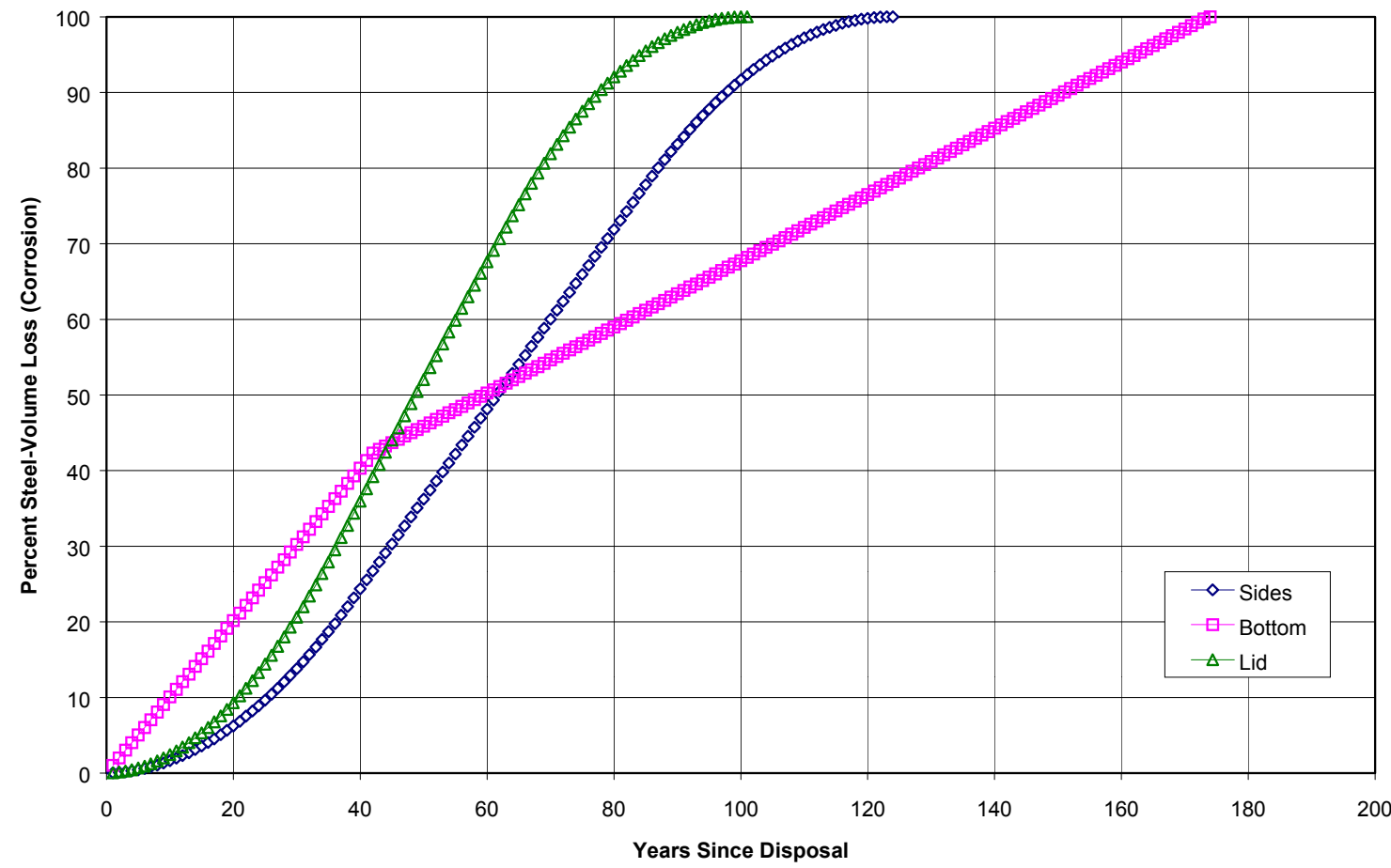

Figure 3. Estimated percent B-25 steel-volume loss with time (continuous incipient area method) 


\section{Lid Corrosion Rates}

After eight years of burial, 2 percent of the B-25 box lid was determined to have been impacted by coalesced pitting with an estimated corrosion rate of $2.4 \mathrm{mpy}$, and 20 percent by general pitting with an estimated corrosion rate of $1.7 \mathrm{mpy}$ (Dunn 2002). It is therefore assumed that coalesced pitting is initiated on 0.25 percent of the lid each year (i.e., 2 percent divided by 8 years) and corrodes at 2.4 mpy thereafter. It is further assumed that general pitting is initiated on 2.5 percent of the lid each year (i.e., 20 percent divided by 8 years) and corrodes at 1.7 mpy thereafter. Corrosion is assumed to initiate in this manner each year until 100 percent of the area is undergoing corrosion. In approximately 36 years, 100 percent is undergoing corrosion with approximately 9 percent of the area affected by coalesced pitting corrosion and 91 percent of the area affected by general pitting. With this method the lid is assumed to be 100 percent corroded in 101 years.

\section{Bottom Corrosion Rates}

After eight years of burial, 24 percent of the outside of the B-25 box bottom was subject to general corrosion induced by the use of forklifts with an estimated corrosion rate of $2.6 \mathrm{mpy}$; and 76 percent of the inside of the B-25 box bottom was subjected to general corrosion with an estimated corrosion rate of $0.63 \mathrm{mpy}$. For the bottom it is assumed that all corrosion is initiated in the first year (i.e., all 24 percent of the forklift corrosion and all 76 percent of the inside general corrosion begins the first year). With this method, the bottom is assumed to be 100 percent corroded in 174 years.

\section{Side Corrosion Rates}

After eight years of burial, 20 percent of the B-25 box sides were determined to have been impacted by general pitting, with an estimated corrosion rate of $1.3 \mathrm{mpy}$ (Dunn, 2002). It is therefore assumed that coalesced pitting is initiated on 2.5 percent of the lid each year (i.e., 20 percent divided by 8 years) and corrodes at 1.3 mpy thereafter. Corrosion is assumed to initiate in this manner each year until 100 percent of the area is undergoing corrosion, which is assumed to occur in approximately 40 years. With this method, the bottom is assumed to be 100 percent corroded in 124 years.

\subsection{SLOWING CORROSION METHOD}

A third, volume-loss rate may be estimated by adjusting pit growth rate to slow (decrease) with time. According to Bradford (2001), maximum pit depth (p) varies with time (t) according to the equation:

$$
\mathrm{p}=k \mathrm{t}^{n}
$$

where $k$ and $n$ are constants.

If pitting does not slow, $n$ equals 1 . A higher value for $n$ (approaching 0.8 ) applies to very poorly aerated soils. A higher $n$-value also applies to soils containing high concentrations of soluble salts, which may form soluble corrosion products rather than solid protective scale. 
A lower $n$-value (around 0.1) applies to well-aerated soils, where the pitting rate readily slows (Bradford, 2001). For this study, a conservative $n$-value of 0.8 , reflecting poorly aerated soils, has been selected based on the clayey, silty sands and apparent anaerobic conditions observed during the B-25 corrosion study (Dunn, 2001).

To employ this method, the same volume-loss rates (cu.ft./yr) developed using the constant volume method were used for each corrosion type. Total volume loss replaces "p" or maximum pit depth in the Bradford equation, the given year since disposal ( $t$ in the Bradford equation) is raised to the exponent of 0.8 and multiplied by the observed volume-loss rate ( $\mathrm{k}$ in the Bradford equation).

So, the Bradford equation is rewritten as:

$$
\mathrm{V}_{1}=k \mathrm{t}^{0.8}
$$

where, $\mathrm{V}_{1}$ is the total volume lost (cu.ft.), $k$ is the volume-loss rate (cu.ft./yr), and t is the time since disposal (year).

Total volume loss is the combination of the volumes of each type of ongoing corrosion. When one type of corrosion has consumed its designated volume, the remaining corrosion type continues at its given rate until the lid, bottom, or sides mass is 100 percent corroded.

Volume-loss versus time estimates by the third method are included in Figure 4. Tables A7 through A9 in Appendix A contain data and additional explanations for the volume-loss curves in Figure 4.

\section{Lid}

Lid corrosion begins with coalesced and scattered pitting processes. The coalesced pitting is completed after 237 years. Scattered pitting alone continues until 100 percent of the lid is corroded at 1,299 years.

\section{Bottom}

Bottom corrosion begins with rapid corrosion in the area between the risers that is abraded by the forklift tines and general corrosion occurring over the remainder of the bottom. The abraded area is 100 percent corroded after 209 years. General corrosion alone continues until the entire bottom is corroded after 462 years.

\section{Sides}

Only scattered pitting corrosion occurs on the sides. This type corrosion continues until the entire sides' volume is impacted after 1,901 years. 
B-25 Percent Steel-Volume Loss (Corrosion)

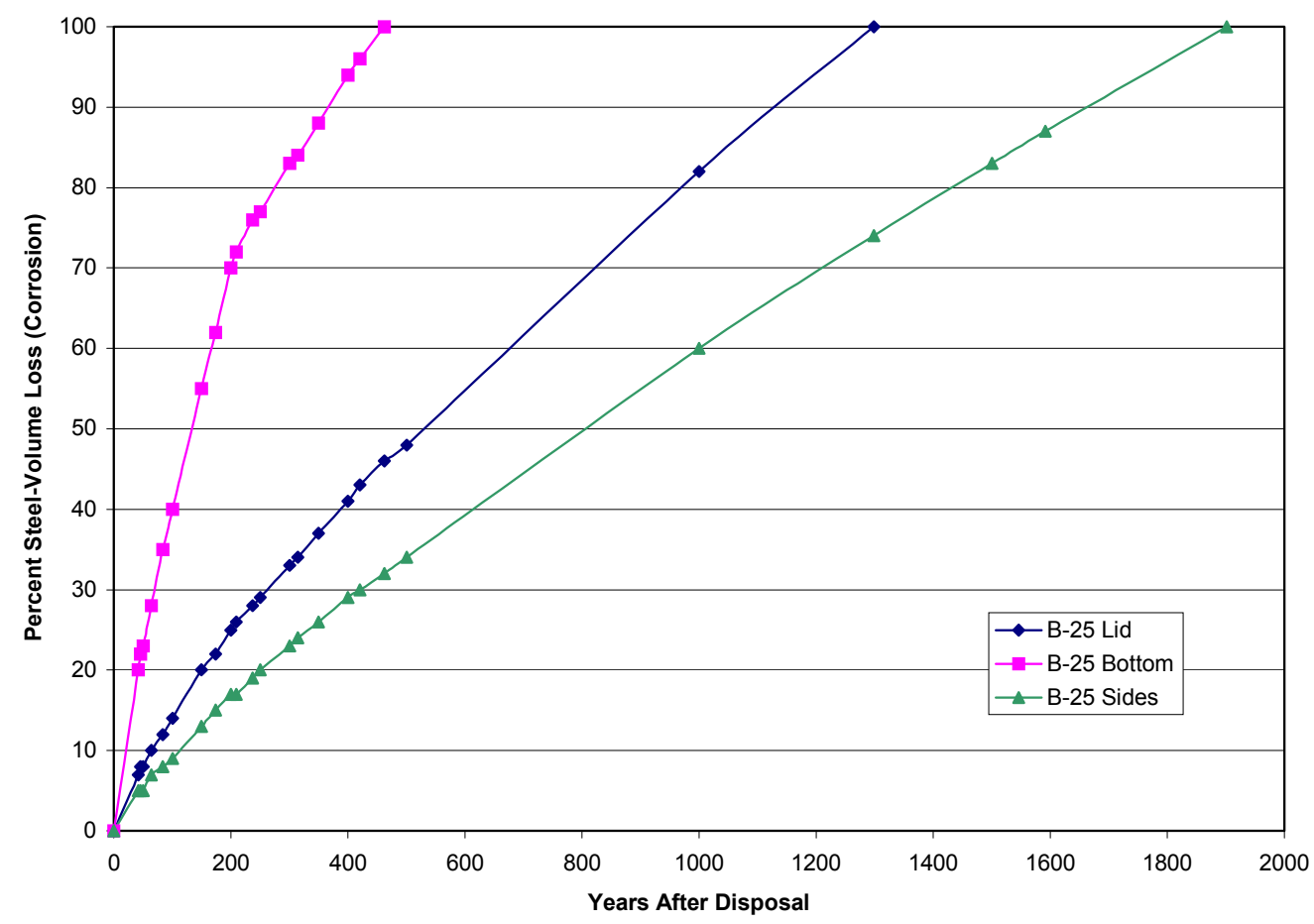

Figure 4. Estimated percent B-25 steel-volume loss with time (slowing corrosion method) 


\subsection{WASTE CHARACTERISTICS}

Gong (2001) assumes two waste types for the initial finite element modeling. The modeling parameters for the two waste types are based on Celotex ${ }^{\mathrm{TM}}$ (a man-made packaging material manufactured from sugarcane fibers) properties. The average waste density of $0.1785 \mathrm{~g} / \mathrm{cm}^{3}$ $\left(178.5 \mathrm{~kg} / \mathrm{m}^{3}\right)$ documented in Phifer and Wilhite (2001) for uncompacted waste is used here because SRS Solid Waste Division plans on placing compacted waste in the E-Area Vaults and uncompacted waste in trenches (SWD-SWO-2001-00039, 2001). Although the ET will contain some compacted waste, the density for uncompacted waste is more representative of the waste density for materials going into trenches in the future, and is also a more conservative (i.e., will yield greater subsidence) value than a denser value.

The $178.5 \mathrm{~kg} / \mathrm{m}^{3}$ density falls below the Gong (2001) density values of $200.308 \mathrm{~kg} / \mathrm{m}^{3}$ and $240.308 \mathrm{~kg} / \mathrm{m}^{3}$. It is closest to Gong (2001)'s Waste Type 1 value, therefore the parameters for Waste Type 1 will be used. Those values are:

\section{Parameter}

Density $(\mathrm{kg} / \mathrm{m} 3)$

Modulus of Elasticity $(\mathrm{Pa})$

Poisson's Ratio

Initial Yield Surface Position

Strength in Hydrostatic Tension (Pa)

Initial Yield Stress in Uniaxial Compression (Pa)

\section{Waste Type 1}

200.308

$2.54765 \mathrm{E}+08$

0.0

1.15

$2.02327 \mathrm{E}+04$

$5.10040 \mathrm{E}+05$

\section{Waste Container Variability}

Containers placed in the ET Phase 1 are primarily B-25 containers of the type described in Jones and $\mathrm{Li}$ (2001). A smaller number of other containers have also been placed. These containers include 55-gal. drums, B-12 containers (similar in construction to, and about half the size of B-25 containers), and blue B-25-size containers. Because the B-25 containers modeled by Gong (2001) are by far the most common type in the ET, these containers alone will continue to be modeled as most representative of ET container behavior. 
This page intentionally left blank.

Page 16 of 36 


\subsection{STATIC M ODELING INPUT}

Static structural finite element modeling reflects consolidation behavior resulting from static loading rather than dynamic compaction. The static modeling objective is to evaluate the behavior of B-25s, soil, and waste under certain static soil loads in regard to different B-25 steel thickness. As corrosion progresses, the steel in the B-25 lid, bottom, and sides is assumed to structurally behave as "thinner" steel. At some point, the load of the soil column overlaying a B-25 stack will overcome the weakening B-25 lids and bottoms and begin to move downward through the B-25 interiors. The steel-volume loss calculations presented in Figure 2, Figure 3, and Figure 4 have been used to identify several sets of lid, bottom, and sides' thickness that may be used in the static modeling. The B-25 thicknesses are summarized in Table 4 through Table 6.

Table 4. B-25 Thickness for Static Modeling (from Constant Volume Method)

\begin{tabular}{|c|c|c|c|c|c|c|}
\hline $\begin{array}{c}\text { Years } \\
\text { Since } \\
\text { Disposal }\end{array}$ & $\begin{array}{c}\text { Lid } \\
\text { Percent } \\
\text { Loss }\end{array}$ & $\begin{array}{c}\text { Lid } \\
\text { Thickness } \\
\text { (in.) }\end{array}$ & $\begin{array}{c}\text { Bottom } \\
\text { Percent } \\
\text { Loss }\end{array}$ & $\begin{array}{c}\text { Bottom } \\
\text { Thickness } \\
\text { (in.) }\end{array}$ & $\begin{array}{c}\text { Sides } \\
\text { Percent } \\
\text { Loss }\end{array}$ & $\begin{array}{c}\text { Sides } \\
\text { Thickness } \\
\text { (in.) }\end{array}$ \\
\hline 42 & 15 & 0.0930 & 42 & 0.0635 & 10 & 0.0985 \\
\hline 64 & 22 & 0.0853 & 52 & 0.0525 & 15 & 0.0930 \\
\hline 100 & 33 & 0.0733 & 68 & 0.0350 & 24 & 0.0831 \\
\hline 150 & 49 & 0.0558 & 89 & 0.0120 & 36 & 0.0700 \\
\hline 174 & 56 & 0.0481 & 100 & 0.0000 & 41 & 0.0645 \\
\hline 237 & 76 & 0.0263 & 100 & 0.0000 & 56 & 0.0481 \\
\hline
\end{tabular}

Table 5. B-25 Thickness for Static Modeling (from Continuous Incipient Area Method)

\begin{tabular}{|c|c|c|c|c|c|c|}
\hline $\begin{array}{c}\text { Years } \\
\text { Since } \\
\text { Disposal }\end{array}$ & $\begin{array}{c}\text { Lid } \\
\text { Percent } \\
\text { Loss }\end{array}$ & $\begin{array}{c}\text { Lid } \\
\text { Thickness } \\
\text { (in.) }\end{array}$ & $\begin{array}{c}\text { Bottom } \\
\text { Percent } \\
\text { Loss }\end{array}$ & $\begin{array}{c}\text { Bottom } \\
\text { Thickness } \\
\text { (in.) }\end{array}$ & $\begin{array}{c}\text { Sides } \\
\text { Percent } \\
\text { Loss }\end{array}$ & $\begin{array}{c}\text { Sides } \\
\text { Thickness } \\
\text { (in.) }\end{array}$ \\
\hline 42 & 39.2 & 0.0665 & 42.3 & 0.0631 & 26.7 & 0.0802 \\
\hline 50 & 52 & 0.0525 & 45.9 & 0.0592 & 36.2 & 0.0698 \\
\hline 68 & 79.3 & 0.0226 & 53.8 & 0.0505 & 57.6 & 0.0464 \\
\hline 124 & 100 & 0.0000 & 78.3 & 0.0237 & 100 & 0.0000 \\
\hline
\end{tabular}


Table 6. B-25 Thickness for Static Modeling (from Slowing Corrosion Method)

\begin{tabular}{|c|c|c|c|c|c|c|}
\hline $\begin{array}{c}\text { Years } \\
\text { Since } \\
\text { Disposal }\end{array}$ & $\begin{array}{c}\text { Lid } \\
\text { Percent } \\
\text { Loss }\end{array}$ & $\begin{array}{c}\text { Lid } \\
\text { Thickness } \\
\text { (in.) }\end{array}$ & $\begin{array}{c}\text { Bottom } \\
\text { Percent } \\
\text { Loss }\end{array}$ & $\begin{array}{c}\text { Bottom } \\
\text { Thickness } \\
\text { (in.) }\end{array}$ & $\begin{array}{c}\text { Sides } \\
\text { Percent } \\
\text { Loss }\end{array}$ & $\begin{array}{c}\text { Sides } \\
\text { Thickness } \\
\text { (in.) }\end{array}$ \\
\hline 64 & 10 & 0.0985 & 28 & 0.0788 & 7 & 0.1017 \\
\hline 150 & 20 & 0.0875 & 55 & 0.0492 & 13 & 0.0952 \\
\hline 250 & 29 & 0.0777 & 77 & 0.0252 & 20 & 0.0875 \\
\hline 462 & 46 & 0.0591 & 100 & 0.0000 & 32 & 0.0744 \\
\hline 1000 & 82 & 0.0197 & 100 & 0.0000 & 60 & 0.0438 \\
\hline
\end{tabular}




\subsection{SUMMAR Y}

Three methods have been used to project the corrosion of ET B-25 containers through time. All three methods are based upon corrosion types and rates observed for a B-25 exhumed in May 2001 (Dunn, 2002).

The Constant Volume Method assumes that the observed annual volume of steel corroded continues into the future without change until the entire B-25 volume is corroded. This is considered to reflect a linear corrosion rate.

The Continuous Incipient Area Method converts the percent area observed impacted to an annual percent area that newly begins to corrode at the observed rates. This method essentially represents increasing corrosion over time.

The Slowing Corrosion Method follows the Constant Volume Method approach and raises the time since disposal (years) to an exponent of 0.8 to slow the corrosion rate with time. This method is based on a method presented in Bradford (2001), where maximum pit depth (p) varies with time $(\mathrm{t})$ according to the equation:

$$
\mathrm{p}=k \mathrm{t}^{n}
$$

where $k$ and $n$ are constants.

For this study, $\mathrm{p}$ is replaced with total volume loss $\left(\mathrm{V}_{1}\right)$ in cu. $\mathrm{ft}$., $k$ is the observed rate of volume-loss in cu.ft./yr, and $n$ is 0.8 . This method is an effort to incorporate the potential for corrosion to slow with time, and presents less aggressive corrosion rates. Predictions using the three methods described herein are based on essentially one data point, the single exhumed B-25 described in Dunn (2002). Additional data points (i.e., exhuming and studying remaining buried B-25s in the future) would provide additional data points to indicate which of these three methods offers the best predictive tool.

Recommendations for quasi-static modeling of B-25 subsidence waste characteristics and steel thickness are included. Although the ET will have containers other than B-25s, only B-25s will be modeled since they are the most common container. 
This page intentionally left blank.

Page 20 of 36 


\subsection{BIBLIOGR APHY}

Bradford, Samuel A., (2001), Practical Handbook of Corrosion Control in Soils, Casti Publishing, Inc. Edmonton, Alberta, Canada.

Cook, James R., Wilhite, Elmer L., and Young, Karen E. (2000), Closure Plan for the E-Area Low-Level Waste Facility, WSRC-RP-2000-00425, Revision 1, October 12, 2000, Westinghouse Savannah River Company, Aiken, SC 29808.

Dunn, Kerry (2002), B-25 Corrosion Evaluation Summary Report (U), WSRC-TR-200100587, January 2002, Westinghouse Savannah River Company, Aiken, SC 29808.

Glover, Thomas J. (2001), Pocket Ref, Sequoia Publishing, Inc., Littleton, Colorado.

Gong, Chung (2001), Finite Element Analysis of Dynamic Compaction of a Stack of Four B25 Containers (U), WSRC-TR-2001-00320, August 2001, Westinghouse Savannah River Company, Aiken, SC 29808.

GSE product data sheet for Bentofix ${ }^{\circledR}$ NSL at http://www.gseworld.com/global/United States/Products/Bentodix/Index.htm

Johnson and Jensen 2001. Transmittal of Test Results for: Old Burial Ground Cap, Geotechnical Testing services, WSRC Site Wide-Task Release No. 61, Law Engineering Project No. 50161-7-0108 (Phase 61). Johnson, H. E. and Jensen, D. M. Law Engineering and Environmental Services, Inc., Atlanta, Georgia, January 29, 2001.

Jones, William E., and Li, William (2001), Long-Term Waste Stabilization Parameter Estimation, Savannah River Site, Aiken, South Carolina (U), WSRC-TR-2001-00323, September 2001, Westinghouse Savannah River Company, Aiken, SC 29808.

McDowell-Boyer, Laura, Yu, Andrew D., Cook, James R., Kocher, David C., Wilhite, Elmer L., Holmes-Burns, Heather, and Young, Karen E. (2000), Radiological Performance Assessment for the E-Area Low-Level Waste Facility, WSRC-RP-94-218. Revision 1, January 31, 2000, Westinghouse Savannah River Company, Aiken, SC 29808.

Nozaki, A., McGrail, B. P., Fayer, M. J., and Saripalli, K. P. (2001), A Coupled MechanicalChemical Stability Analysis for a Low Activity Waste Disposal Facility at the Hanford Site, Computers and Structures, Vol. 79, pps. 1503-1516, Pergamon Press.

Phifer, M. A., "Closure of a Mixed Waste Landfill - Lessons Learned,” Tucson, Arizona: Waste Management 91 Symposia, pp. 517-525 (1991).

Phifer, Mark A. and Wilhite, Elmer L. (2001), Waste Subsidence Potential Versus Supercompaction, WSRC-RP-2001-00613, September 27, 2001, Westinghouse Savannah River Company, Aiken, SC 29808.

Saltstone Design Equivalency Demonstration, WSRC-TR-2002-00236, Draft, Westinghouse Savannah River Company, Aiken, SC 29808. 
This page intentionally left blank.

Page 22 of 36 
APPENDIX A

\section{STEEL-VOLUME LOSS ESTIMATES}

\section{LIST OF TABLES}

Table A1. Constant Volume Method - Lid Percent Volume Loss Over Time.......................................25

Table A2. Constant Volume Method - Bottom Percent Volume Loss Over Time .................................26

Table A3. Constant Volume Method - Sides Percent Volume Loss Over Time.....................................27

Table A4. Continuous Incipient Area Method - Lid Percent Volume Loss Over Time .........................28

Table A5. Continuous Incipient Area Method - Bottom Percent Volume Loss Over Time ....................29

Table A6. Continuous Incipient Area Method - Sides Percent Volume Loss Over Time........................31

Table A7. Slowing Corrosion Method - Lid Percent Volume Loss Over Time.......................................32

Table A8. Slowing Corrosion Method - Bottom Percent Volume Loss Over Time ...............................34

Table A9. Slowing Corrosion Method - Sides Percent Volume Loss Over Time ..................................36 
This page intentionally left blank. 
Table A1. Constant Volume Method - Lid Percent Volume Loss Over Time

B-25 Inside

(sq. ft./cu. ft.)

(area $=23.00$ sq. ft.)

(volume $=0.21 \mathrm{cu} . \mathrm{ft}$.)

(thickness $=0.009116 \mathrm{ft}$.)

$\begin{array}{ll}\text { Coalesced Pitting } & 2 \\ \text { Scattered Pitting } & 20 \\ \text { Scattered Pitting } & 20 \\ \text { Scattered Pitting } & 20 \\ \text { Scattered Pitting } & 20 \\ \text { Scattered Pitting } & 20 \\ \text { Scattered Pitting } & 20 \\ \text { Scattered Pitting } & 20 \\ \text { Scattered Pitting } & 20 \\ \text { Scattered Pitting } & 20 \\ \text { Scattered Pitting } & 20 \\ \text { Scattered Pitting } & 20 \\ \text { Scattered Pitting } & 20\end{array}$

Comments:

B-25 inside dimensions $3 \mathrm{ft} 10$ in. width $\times 6 \mathrm{ft}$. length $\times 3 \mathrm{ft} 10 \mathrm{in}$. height.

$\mathrm{B}-25 \mathrm{lid}$, bottom, and side-wall thickness is $0.009116 \mathrm{ft}$.

2 percent lid area coalesced pitting (corrosion rate $2.4 \mathrm{mils} / \mathrm{yr}$ ).

20 percent lid area comprised of scattered pits (corrosion rate $1.7 \mathrm{mils} / \mathrm{yr}$ ).

Assume steel volume reduction rate is volume impacted/thru-wall penetration years.

Assume volume reduction is original volume minus volume reduction rate(s) $\mathrm{x}$ number of

years since disposal.

Assume volume reduction at $64 \mathrm{yrs}$. is sum of coalesced pitting rate and scattered pitting

rates volume losses.

Assume volume reduction rate after 64 years is at rate for scattered pitting only

${ }^{1}$ From Dunn (2002)

${ }^{2}$ Area Impacted (sq. ft.) = Area Impacted (percent) $x$ Area of lid, bottom or sides. Volume Impacted (cu. ft.) = Area Impacted (cu.ft.) $x$ thickness (ft.)

${ }^{3}$ Steel-volume reduction rate $=$ Volume Impacted (cu.ft.)/Thru-wall Penetration (years).

${ }^{4}$ Volume Reduction (cu. ft.) = Steel-Volume Reduction Rate(s) x Years Since Disposal (summed where more than one type corrosion occurring)

${ }^{5}$ Volume Reduction (percent) $=($ Volume Reduction (cu. ft.) $/$ Total Volume of lid, bottom or sides) $x 100$.
$0.0000913 \mathrm{cu} \mathrm{ft} / \mathrm{yr}$ $0.0006547 \mathrm{cu} \mathrm{ft} / \mathrm{yr}$ $0.0006547 \mathrm{cu} \mathrm{ft} / \mathrm{yr}$ $0.0006547 \mathrm{cu} \mathrm{ft} / \mathrm{yr}$ $0.0006547 \mathrm{cu} \mathrm{ft} / \mathrm{yr}$ $0.0006547 \mathrm{cu} \mathrm{ft} / \mathrm{yr}$ $0.0006547 \mathrm{cu} \mathrm{ft} / \mathrm{yr}$ $0.0006547 \mathrm{cu} \mathrm{ft} / \mathrm{yr}$ $0.0006547 \mathrm{cu} \mathrm{ft} / \mathrm{yr}$ $0.0006547 \mathrm{cu} \mathrm{ft} / \mathrm{yr}$ $0.0006547 \mathrm{cu} \mathrm{ft} / \mathrm{yr}$ $0.0006547 \mathrm{cu} \mathrm{ft} / \mathrm{yr}$ $0.0006547 \mathrm{cu} \mathrm{ft} / \mathrm{yr}$

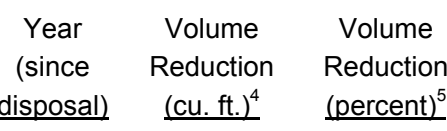


Table A2. Constant Volume Method - Bottom Percent Volume Loss Over Time

B-25 Inside

(sq. ft./cu. ft.)

\section{Bottom}

(area $=23.00$ sq. ft.)

(volume $=0.21 \mathrm{cu} . \mathrm{ft}$ )

(thickness $=0.009116 \mathrm{ft}$.)

$\begin{array}{cc} & \text { Area } \\ \text { Type } & \text { Impacted } \\ \text { Corrosion } & \text { (percent) }^{1}\end{array}$

Area
Impacted
$\underline{\text { (sq. ft. })^{2}}$

$\begin{array}{cc}\text { Volume } & \text { Thru-Wall } \\ \text { Impacted } & \text { Penetration } \\ \text { (cu. ft.) }^{2} & \text { (years) }^{1}\end{array}$

\begin{tabular}{c} 
Steel-Volume \\
Reduction Rate \\
(vol. impacted/thru-wall yrs.) \\
\hline
\end{tabular}

\begin{tabular}{c} 
Year \\
(since \\
disposal) \\
\hline
\end{tabular}

Volume

Reduction

${\text { (cu. ft. })^{4}}^{4}$

Reduction

(percent) $^{5}$

$\begin{array}{cccc}\text { Abraided Area } & 24 & 5.52 & 0.0503 \\ \text { General Corrosion } & 76 & 17.48 & 0.1593 \\ \text { General Corrosion } & 76 & 17.48 & 0.1593 \\ \text { General Corrosion } & 76 & 17.48 & 0.1593 \\ \text { General Corrosion } & 76 & 17.48 & 0.1593 \\ \text { General Corrosion } & 76 & 17.48 & 0.1593 \\ \text { General Corrosion } & 76 & 17.48 & 0.1593 \\ \text { General Corrosion } & 76 & 17.48 & 0.1593\end{array}$
$0.0011976 \mathrm{cu} \mathrm{ft} / \mathrm{yr}$
$0.0009155 \mathrm{cu} \mathrm{ft} / \mathrm{yr}$
$0.0009155 \mathrm{cu} \mathrm{ft} / \mathrm{yr}$
$0.0009155 \mathrm{cu} \mathrm{ft} / \mathrm{yr}$
$0.0009155 \mathrm{cu} \mathrm{ft} / \mathrm{yr}$
$0.0009155 \mathrm{cu} \mathrm{ft} / \mathrm{yr}$
$0.0009155 \mathrm{cu} \mathrm{ft} / \mathrm{yr}$
$0.0009155 \mathrm{cu} \mathrm{ft} / \mathrm{yr}$

0.0888
0.0924
0.0961
0.1089
0.1272
0.1419
0.1876
$\mathbf{0 . 2 0 9 6}$

Comments:

Abraded area corrosion rate $2.6 \mathrm{mils} / \mathrm{yr}$. General corrosion rate $0.63 \mathrm{mils} / \mathrm{yr}$.

Assume volume reduction at 42 years is total volume from forklift-abraded area

rate plus volume prorated volume from general-corrosion area rate.

Assume volume reduction rate after 42 years is at rate for general corrosion.

${ }^{1}$ From Dunn (2002)

${ }^{2}$ Area Impacted (sq. ft.) = Area Impacted (percent) $x$ Area of lid, bottom or sides. Volume Impacted (cu. ft.) = Area Impacted (cu.ft.) $x$ thickness (ft.).

${ }^{3}$ Steel-volume reduction rate $=$ Volume Impacted (cu.ft.)/Thru-wall Penetration (years).

${ }^{4}$ Volume Reduction (cu. ft.) = Steel-Volume Reduction Rate(s) x Years Since Disposal (summed where more than one type corrosion occurring).

${ }^{5}$ Volume Reduction (percent) $=($ Volume Reduction $(\mathrm{cu}$. ft. $) /$ Total Volume of lid, bottom or sides $) \times 100$. 
Table A3. Constant Volume Method - Sides Percent Volume Loss Over Time

\author{
B-25 Inside
}

(sq. ft./cu. ft.)

\section{Sides}

(area $=77.02)$

(volume $=0.702$ cu.ft.)

(thickness $=0.009116 \mathrm{ft}$.)

\section{Comments:}

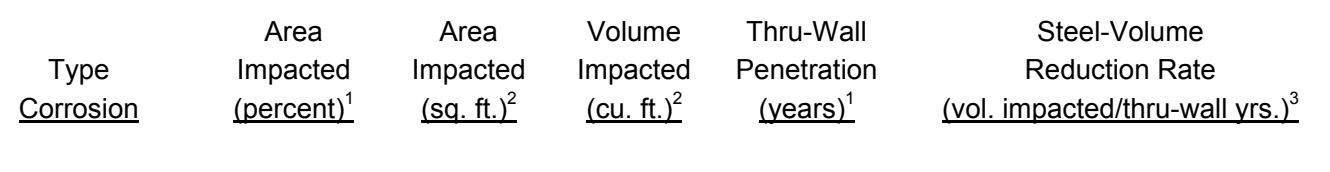

\begin{tabular}{|c|c|c|}
\hline $\begin{array}{l}\text { Year } \\
\text { (since } \\
\text { disposal) }\end{array}$ & $\begin{array}{l}\text { Volume } \\
\text { Reduction } \\
\text { (cu. ft. })^{4}\end{array}$ & $\begin{array}{l}\text { Volume } \\
\text { Reduction } \\
\text { (percent) }^{5}\end{array}$ \\
\hline
\end{tabular}

$\begin{array}{lllll}\text { Scattered Pitting } & 20 & 15.404 & 0.1404 & 84 \\ \text { Scattered Pitting } & 20 & 15.404 & 0.1404 & 84 \\ \text { Scattered Pitting } & 20 & 15.404 & 0.1404 & 84 \\ \text { Scattered Pitting } & 20 & 15.404 & 0.1404 & 84 \\ \text { Scattered Pitting } & 20 & 15.404 & 0.1404 & 84 \\ \text { Scattered Pitting } & 20 & 15.404 & 0.1404 & 84 \\ \text { Scattered Pitting } & 20 & 15.404 & 0.1404 & 84 \\ \text { Scattered Pitting } & 20 & 15.404 & 0.1404 & 84 \\ \text { Scattered Pitting } & 20 & 15.404 & 0.1404 & 84 \\ \text { Scattered Pitting } & 20 & 15.404 & 0.1404 & 84 \\ \text { Scattered Pitting } & 20 & 15.404 & 0.1404 & 84 \\ \text { Scattered Pitting } & 20 & 15.404 & 0.1404 & 84 \\ \text { Scattered Pitting } & 20 & 15.404 & 0.1404 & 84 \\ \text { Scattered Pitting } & 20 & 15.404 & 0.1404 & 84 \\ \text { Scattered Pitting } & 20 & 15.404 & 0.1404 & 84 \\ \text { Scattered Pitting } & 20 & 15.404 & 0.1404 & 84 \\ \text { Scattered Pitting } & 20 & 15.404 & 0.1404 & 84\end{array}$

Scattered pitting corrosion rate 1.3 mils/yr.

Assume single, constant volume reduction rate.

${ }^{1}$ From Dunn (2002)

${ }^{2}$ Area Impacted (sq. ft.) = Area Impacted (percent) $x$ Area of lid, bottom or sides. Volume Impacted (cu. ft.) = Area Impacted (cu.ft.) $x$ thickness (ft.). ${ }^{3}$ Steel-volume reduction rate $=$ Volume Impacted (cu.ft.)/Thru-wall Penetration (years).

${ }^{4}$ Volume Reduction (cu. ft.) = Steel-Volume Reduction Rate(s) x Years Since Disposal (summed where more than one type corrosion occurring).

${ }^{5}$ Volume Reduction (percent) $=($ Volume Reduction (cu. ft.) / Total Volume of lid, bottom or sides) $\times 100$. 
Table A4. Continuous Incipient Area Method - Lid Percent Volume Loss Over Time

\begin{tabular}{|c|c|c|c|c|c|c|c|c|c|c|c|c|c|c|c|}
\hline Years & 1 & 2 & 3 & 4 & 5 & 6 & 7 & 8 & 9 & 10 & 11 & 12 & 13 & 14 & 15 \\
\hline Percent & 0.04 & 0.13 & 0.27 & 0.44 & 0.66 & 0.93 & 1.24 & 1.60 & 1.99 & 2.44 & 2.93 & 3.46 & 4.03 & 4.65 & 5.32 \\
\hline Years & 16 & 17 & 18 & 19 & 20 & 21 & 22 & 23 & 24 & 25 & 26 & 27 & 28 & 29 & 30 \\
\hline Percent & 6.03 & 6.78 & 7.58 & 8.42 & 9.31 & 10.24 & 11.22 & 12.24 & 13.30 & 14.41 & 15.56 & 16.76 & 18.00 & 19.28 & 20.61 \\
\hline Years & 31 & 32 & 33 & 34 & 35 & 36 & 37 & 38 & 39 & 40 & 41 & 42 & 43 & 44 & 45 \\
\hline Percent & 21.99 & 23.41 & 24.87 & 26.38 & 27.93 & 29.53 & 31.14 & 32.75 & 34.36 & 35.97 & 37.59 & 39.20 & 40.81 & 42.42 & 44.03 \\
\hline Years & 46 & 47 & 48 & 49 & 50 & 51 & 52 & 53 & 54 & 55 & 56 & 57 & 58 & 59 & 60 \\
\hline Percent & 45.64 & 47.25 & 48.85 & 50.44 & 52.03 & 53.61 & 55.19 & 56.76 & 58.33 & 59.89 & 61.44 & 62.99 & 64.53 & 66.07 & 67.61 \\
\hline Years & 61 & 62 & 63 & 64 & 65 & 66 & 67 & 68 & 69 & 70 & 71 & 72 & 73 & 74 & 75 \\
\hline Percent & 69.13 & 70.66 & 72.17 & 73.68 & 75.16 & 76.60 & 77.99 & 79.34 & 80.64 & 81.90 & 83.12 & 84.29 & 85.41 & 86.49 & 87.53 \\
\hline Years & 76 & 77 & 78 & 79 & 80 & 81 & 82 & 83 & 84 & 85 & 86 & 87 & 88 & 89 & 90 \\
\hline Percent & 88.52 & 89.47 & 90.38 & 91.24 & 92.05 & 92.82 & 93.55 & 94.24 & 94.89 & 95.50 & 96.07 & 96.60 & 97.10 & 97.55 & 97.97 \\
\hline Years & 91 & 92 & 93 & 94 & 95 & 96 & 97 & 98 & 99 & 100 & 101 & & & & \\
\hline Percent & 98.35 & 98.68 & 98.98 & 99.25 & 99.47 & 99.65 & 99.80 & 99.90 & 99.97 & 100.00 & 100.00 & & & & \\
\hline
\end{tabular}


Table A5. Continuous Incipient Area Method - Bottom Percent Volume Loss Over Time

\begin{tabular}{|c|c|c|c|c|c|c|c|c|c|c|c|c|c|c|c|}
\hline Years & 1 & 2 & 3 & 4 & 5 & 6 & 7 & 8 & 9 & 10 & 11 & 12 & 13 & 14 & 15 \\
\hline Percent & 1.01 & 2.02 & 3.02 & 4.03 & 5.04 & 6.05 & 7.06 & 8.06 & 9.07 & 10.08 & 11.09 & 12.10 & 13.10 & 14.11 & 15.12 \\
\hline Years & 16 & 17 & 18 & 19 & 20 & 21 & 22 & 23 & 24 & 25 & 26 & 27 & 28 & 29 & 30 \\
\hline Percent & 16.13 & 17.14 & 18.14 & 19.15 & 20.16 & 21.17 & 22.18 & 23.19 & 24.19 & 25.20 & 26.21 & 27.22 & 28.23 & 29.23 & 30.24 \\
\hline Years & 31 & 32 & 33 & 34 & 35 & 36 & 37 & 38 & 39 & 40 & 41 & 42 & 43 & 44 & 45 \\
\hline Percent & 31.25 & 32.26 & 33.27 & 34.27 & 35.28 & 36.29 & 37.30 & 38.31 & 39.31 & 40.32 & 41.33 & 42.34 & 42.82 & 43.26 & 43.69 \\
\hline Years & 46 & 47 & 48 & 49 & 50 & 51 & 52 & 53 & 54 & 55 & 56 & 57 & 58 & 59 & 60 \\
\hline Percent & 44.13 & 44.57 & 45.01 & 45.45 & 45.88 & 46.32 & 46.76 & 47.20 & 47.63 & 48.07 & 48.51 & 48.95 & 49.38 & 49.82 & 50.26 \\
\hline Years & 61 & 62 & 63 & 64 & 65 & 66 & 67 & 68 & 69 & 70 & 71 & 72 & 73 & 72 & 75 \\
\hline Percent & 50.70 & 51.13 & 51.57 & 52.01 & 52.45 & 52.89 & 53.32 & 53.76 & 54.20 & 54.64 & 55.07 & 55.51 & 55.95 & 56.39 & 56.82 \\
\hline Years & 76 & 77 & 78 & 79 & 80 & 81 & 82 & 83 & 84 & 85 & 86 & 87 & 88 & 89 & 90 \\
\hline Percent & 57.26 & 57.70 & 58.14 & 58.58 & 59.01 & 59.45 & 59.89 & 60.33 & 60.76 & 61.20 & 61.64 & 62.08 & 62.51 & 62.95 & 63.39 \\
\hline Years & 91 & 92 & 93 & 94 & 95 & 96 & 97 & 98 & 99 & 10 & 10 & 10 & 10 & 1 & 105 \\
\hline Percent & 63.83 & 64.26 & 64.70 & 65.14 & 65.58 & 66.02 & 66.45 & 66.89 & 67.33 & 67.77 & 68.20 & 68.64 & 69.08 & 69.52 & 69.95 \\
\hline Year & 106 & 107 & 108 & 109 & 110 & 11 & 112 & 11 & & 11 & 11 & 11 & 11 & 11 & 120 \\
\hline Percent & 70.39 & 70.83 & 71.27 & 71.70 & 72.14 & 72.58 & 73.02 & 73.46 & 73.89 & 74.33 & 74.77 & 75.21 & 75.64 & 76.08 & 76.52 \\
\hline Yea & 21 & 122 & 123 & 124 & 125 & 126 & 127 & 128 & 129 & 130 & 131 & 132 & 133 & 13 & 135 \\
\hline Percent & 76.96 & 77.39 & 77.83 & 78.27 & 78.71 & 79.15 & 79.58 & 80.02 & 80.46 & 80.90 & 81.33 & 81.77 & 82.21 & 82.65 & 83.08 \\
\hline
\end{tabular}


Table A5. Continuous Incipient Area Method - Bottom Percent Volume Loss Over Time - continued

\begin{tabular}{|c|c|c|c|c|c|c|c|c|c|c|c|c|c|c|c|}
\hline Years & 136 & 137 & 138 & 139 & 140 & 141 & 142 & 143 & 144 & 145 & 146 & 147 & 148 & 149 & 150 \\
\hline Percent & 83.52 & 83.96 & 84.40 & 84.83 & 85.27 & 85.71 & 86.15 & 86.59 & 87.02 & 87.46 & 87.90 & 88.34 & 88.77 & 89.21 & 89.65 \\
\hline Years & 151 & 152 & 153 & 154 & 155 & 156 & 157 & 158 & 159 & 160 & 161 & 162 & 163 & 164 & 165 \\
\hline Percent & 90.09 & 90.52 & 90.96 & 91.40 & 91.84 & 92.27 & 92.71 & 93.15 & 93.59 & 94.03 & 94.46 & 94.90 & 95.34 & 95.78 & 96.21 \\
\hline Years & 166 & 167 & 168 & 169 & 170 & 171 & 172 & 173 & $1 / 4$ & & & & & & \\
\hline Percent & 96.65 & 97.09 & 97.53 & 97.96 & 98.40 & 98.84 & 99.28 & 99.72 & 100.00 & & & & & & \\
\hline
\end{tabular}


Table A6. Continuous Incipient Area Method - Sides Percent Volume Loss Over Time

\begin{tabular}{|c|c|c|c|c|c|c|c|c|c|c|c|c|c|c|c|}
\hline Years & 1 & 2 & 3 & 4 & 5 & 6 & 7 & 8 & 9 & 10 & 11 & 12 & 13 & 14 & 15 \\
\hline Percent & 0.03 & 0.09 & 0.18 & 0.30 & 0.45 & 0.62 & 0.83 & 1.07 & 1.34 & 1.63 & 1.96 & 2.32 & 2.70 & 3.12 & 3.56 \\
\hline Years & 16 & 17 & 18 & 19 & 20 & 21 & 22 & 23 & 24 & 25 & 26 & 27 & 28 & 29 & 30 \\
\hline Percent & 4.04 & 4.55 & 5.08 & 5.64 & 6.24 & 6.86 & 7.52 & 8.20 & 8.91 & 9.65 & 10.43 & 11.23 & 12.06 & 12.92 & 13.81 \\
\hline Years & 31 & 32 & 33 & 34 & 35 & 36 & 37 & 38 & 39 & 40 & 41 & 42 & 43 & 44 & 45 \\
\hline Percent & 14.73 & 15.69 & 16.67 & 17.68 & 18.72 & 19.79 & 20.88 & 22.01 & 23.17 & 24.36 & 25.55 & 26.74 & 27.93 & 29.11 & 30.30 \\
\hline Years & 46 & 47 & 48 & 49 & 50 & 51 & 52 & 53 & 54 & 55 & 56 & 57 & 58 & 59 & 60 \\
\hline Percent & 31.49 & 32.68 & 33.87 & 35.05 & 36.24 & 37.43 & 38.62 & 39.81 & 41.00 & 42.18 & 43.37 & 44.56 & 45.75 & 46.94 & 48.13 \\
\hline Years & 61 & 62 & 63 & 64 & 65 & 66 & 67 & 68 & 69 & 70 & 71 & 72 & 73 & 74 & 75 \\
\hline Percent & 49.31 & 50.50 & 51.69 & 52.88 & 54.07 & 55.26 & 56.44 & 57.63 & 58.82 & 60.01 & 61.20 & 62.39 & 63.57 & 64.76 & 65.95 \\
\hline Years & 76 & 77 & 78 & 79 & 80 & 81 & 82 & 83 & 84 & 85 & 86 & 87 & 88 & 89 & 90 \\
\hline Percent & 67.14 & 68.33 & 69.52 & 70.70 & 71.89 & 73.08 & 74.27 & 75.46 & 76.65 & 77.81 & 78.94 & 80.05 & 81.12 & 82.16 & 83.18 \\
\hline Years & 91 & 92 & 93 & 94 & 95 & 96 & 97 & 98 & 99 & 100 & 101 & 102 & 103 & 104 & 105 \\
\hline Percent & 84.16 & 85.12 & 86.04 & 86.94 & 87.81 & 88.64 & 89.45 & 90.23 & 90.97 & 91.69 & 92.38 & 93.04 & 93.67 & 94.26 & 94.83 \\
\hline Years & 106 & 107 & 108 & 109 & 110 & 111 & 112 & 113 & 114 & 115 & 116 & 117 & 118 & 119 & 120 \\
\hline Percent & 95.37 & 95.88 & 96.36 & 96.81 & 97.23 & 97.62 & 97.98 & 98.32 & 98.62 & 98.89 & 99.13 & 99.34 & 99.53 & 99.68 & 99.80 \\
\hline Year & 121 & 122 & 123 & 124 & & & & & & & & & & & \\
\hline Percent & 99.90 & 99.96 & 100.00 & 100.00 & & & & & & & & & & & \\
\hline
\end{tabular}


Table A7. Slowing Corrosion Method - Lid Percent Volume Loss Over Time

\begin{tabular}{|c|c|c|c|c|c|c|c|c|c|c|c|}
\hline B-25 Inside & & Area & Area & Volume & Corrosion & Corrosion & Year & Volume & $\begin{array}{c}\text { Corroded } \\
\text { (percent }\end{array}$ & $\begin{array}{c}\text { Total } \\
\text { Volume }\end{array}$ & $\begin{array}{c}\text { Volume } \\
\text { Reduction }\end{array}$ \\
\hline $\begin{array}{l}\text { Area/Volume } \\
\text { (sq. ft./cu. ft.) }\end{array}$ & $\begin{array}{c}\text { Type } \\
\text { Corrosion }\end{array}$ & $\begin{array}{l}\text { Impacted } \\
\text { (percent) }\end{array}$ & $\begin{array}{l}\text { Impacted } \\
\text { (sq. ft.) })^{2}\end{array}$ & $\begin{array}{l}\text { Impacted } \\
\text { (cu. ft. })^{3}\end{array}$ & $\begin{array}{c}\text { Rate } \\
\text { (mils/yr) }^{1}\end{array}$ & $\begin{array}{c}\text { Rate } \\
\text { (cu.ft/yr) }\end{array}$ & $\begin{array}{c}\text { (since } \\
\text { disposal) }\end{array}$ & $\begin{array}{l}\text { Corroded } \\
{\text { (cu. ft. })^{5}}^{\text {con }}\end{array}$ & $\begin{array}{l}\text { lid/bottom/ } \\
\text { or sides) }\end{array}$ & $\begin{array}{l}\text { Reduction } \\
(\text { cu. ft) })^{7}\end{array}$ & $\begin{array}{c}\text { (percent lid/ } \\
\text { bottom/or sides) }\end{array}$ \\
\hline
\end{tabular}

\section{Lid}

(area $=23.00$ sq. ft.) $\quad$ Coalesced Pitting (volume $=0.21 \mathrm{cu}$. ft.) $\quad$ Scattered Pitting (thickness $=0.009116 \mathrm{ft}$.) $\quad$ Coalesced Pitting (thickness $=109.4$ mils)

\section{Scattered Pitting} Coalesced Pitting Scattered Pitting Coalesced Pitting Scattered Pitting

Coalesced Pitting Scattered Pitting Coalesced Pitting Scattered Pitting Coalesced Pitting Scattered Pitting Coalesced Pitting Scattered Pitting Coalesced Pitting Scattered Pitting Coalesced Pitting Scattered Pitting Coalesced Pitting Scattered Pitting

2
20
2
20
2
20
2
20
2
20
2
20
2
20
2
20
2
20
2
20
2
20

$\begin{array}{cccc}0.46 & 0.0042 & 2.4 & 0.0000913 \\ 4.6 & 0.0419 & 1.7 & 0.0006547 \\ 0.46 & 0.0042 & 2.4 & 0.0000913 \\ 4.6 & 0.0419 & 1.7 & 0.0006547 \\ 0.46 & 0.0042 & 2.4 & 0.0000913 \\ 4.6 & 0.0419 & 1.7 & 0.0006547 \\ 0.46 & 0.0042 & 2.4 & 0.0000913 \\ 4.6 & 0.0419 & 1.7 & 0.0006547 \\ 0.46 & 0.0042 & 2.4 & 0.0000913 \\ 4.6 & 0.0419 & 1.7 & 0.0006547 \\ 0.46 & 0.0042 & 2.4 & 0.0000913 \\ 4.6 & 0.0419 & 1.7 & 0.0006547 \\ 0.46 & 0.0042 & 2.4 & 0.0000913 \\ 4.6 & 0.0419 & 1.7 & 0.0006547 \\ 0.46 & 0.0042 & 2.4 & 0.0000913 \\ 4.6 & 0.0419 & 1.7 & 0.0006547 \\ 0.46 & 0.0042 & 2.4 & 0.0000913 \\ 4.6 & 0.0419 & 1.7 & 0.0006547 \\ 0.46 & 0.0042 & 2.4 & 0.0000913 \\ 4.6 & 0.0419 & 1.7 & 0.0006547 \\ \text { Coalesced Pitting Area 100\% Corroded } & \\ 4.6 & 0.0419 & 1.7 & 0.0006547\end{array}$

0

42

42

46

46
46

50

50

64

64

84

84

100

100

150

150

174

174

200

200

209

209

237

237

$$
\begin{aligned}
& 0.00182 \\
& 0.01302 \\
& 0.00195 \\
& 0.01400 \\
& 0.00209 \\
& 0.01497 \\
& 0.00254 \\
& 0.01824 \\
& 0.00316 \\
& 0.02267 \\
& 0.00363 \\
& 0.02606 \\
& 0.00503 \\
& 0.03605 \\
& 0.00566 \\
& 0.04060 \\
& 0.00633 \\
& 0.04538 \\
& 0.00656 \\
& 0.04701 \\
& 0.00726 \\
& 0.05205
\end{aligned}
$$

0

0.01484

0.01596

0.01706

0.02078

0.02583

0.02970

0.04108

0.04626

0.05171

0.05356

0.05931 
Table A7. Slowing Corrosion Method - Lid Percent Volume Loss Over Time - continued

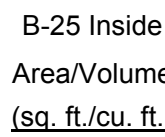

(sq. ft./cu. ft.)

Lid

\begin{tabular}{c} 
Type \\
Corrosion \\
\hline
\end{tabular}

Area
Impacted
(percent) $^{1}$

Area

Impacted

(sq. ft.) $)^{2}$

\begin{tabular}{|c|c|c|c|}
\hline Volume & Corrosion & Corrosion & Year \\
\hline $\begin{array}{l}\text { Impacted } \\
(\mathrm{cu} . \mathrm{ft})^{3}\end{array}$ & $\begin{array}{c}\text { Rate } \\
(\mathrm{mils} / \mathrm{yr})^{1}\end{array}$ & $\begin{array}{c}\text { Rate } \\
(\mathrm{cu} . \mathrm{ft} / \mathrm{yr})^{4}\end{array}$ & $\begin{array}{c}\text { (since } \\
\text { disposal) }\end{array}$ \\
\hline
\end{tabular}

(2)

Volume

Volume

Corroded

Corroded lid/bottom/ Reduction

${\text { (cu. ft. })^{5}}^{5}$

or sides)
Total

Volume

Reduction

(percent lid/

bottom/or sides) ${ }^{8}$

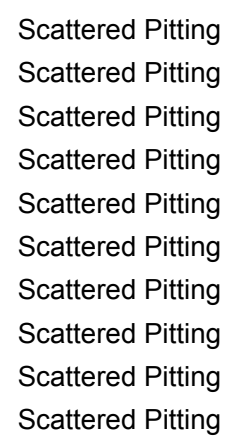

Scattered Pitting Scattered Pitting Scattered Pitting Scattered Pitting Scattered Pitting Scattered Pitting Scattered Pitting Scattered Pitting Scattered Pitting Scattered Pitting

20
20
20
20
20
20
20
20
20
20

$\begin{array}{cc}\text { Scattered Pitting corrosio } \\ 4.6 & 0.0419 \\ 4.6 & 0.0419 \\ 4.6 & 0.0419 \\ 4.6 & 0.0419 \\ 4.6 & 0.0419 \\ 4.6 & 0.0419 \\ 4.6 & 0.0419 \\ 4.6 & 0.0419 \\ 4.6 & 0.0419\end{array}$

\section{0}

300

314

350

400

420

462

500

1000

1299

$$
\begin{aligned}
& 0.05425 \\
& 0.06277 \\
& 0.06510 \\
& 0.07101 \\
& 0.07901 \\
& 0.08216 \\
& 0.08867 \\
& 0.09445 \\
& 0.16445 \\
& \mathbf{0 . 2 0 2 7 5}
\end{aligned}
$$

29

33

$29.89 \quad 0.07003 \quad 33$

$33.81 \quad 0.07826$

$37.62 \quad 0.08627$

$39.12 \quad 0.08942$

$42.22 \quad 0.09592$

$44.98 \quad 0.10171$

$78.31 \quad 0.17171$

$96.55 \quad 0.21001$

Comments:

${ }^{1}$ From Dunn (2002).

${ }^{2}$ Area impacted percent $\mathrm{x}$ total sq. ft. area of total lid, bottom, or 4-sides.

${ }^{3}$ Area impacted (sq. ft.) x thickness $(0.009116 \mathrm{ft}$.).

${ }^{4}$ Volume impacted /number of years for through-wall penetration.

${ }^{5}$ Modified Bradford equation ( vol corroded cu. $\mathrm{ft}=\left(\right.$ years since disposal $\left.{ }^{0.7}\right) \times$ corrosion rate cu. $\left.\mathrm{ft} / \mathrm{yr}\right)$.

${ }^{6}$ (Volume corroded for given corrosion type/total volume) x 100.

${ }^{7}$ Sum of the volumes of the various corrosion types.

${ }^{8}$ Total volume reduction (volume corroded)/ total lid, bottom, or 4-sides' volume. 
Table A8. Slowing Corrosion Method - Bottom Percent Volume Loss Over Time

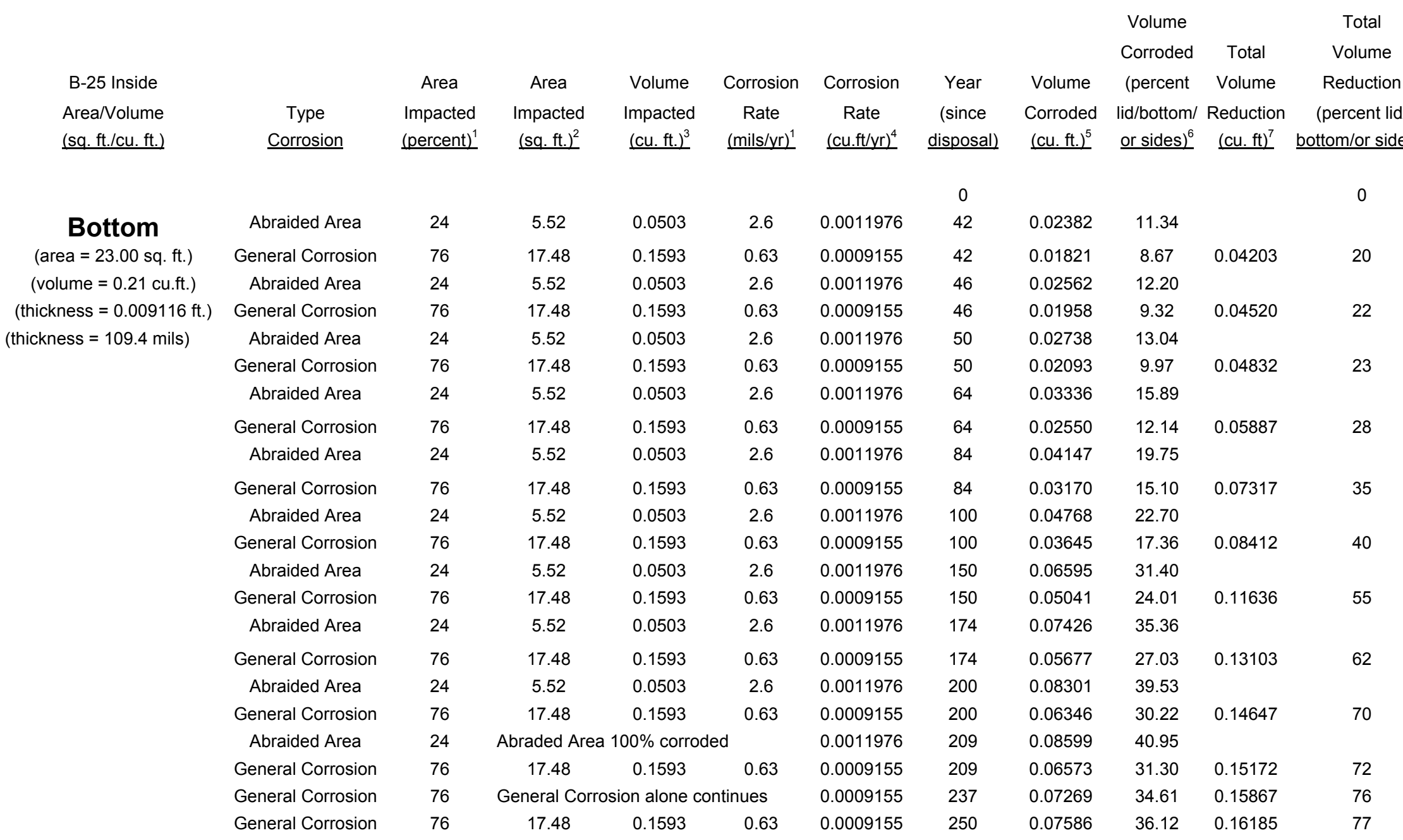


Table A8. Slowing Corrosion Method - Bottom Percent Volume Loss Over Time - continued

\begin{tabular}{|c|c|c|c|c|c|c|c|c|c|c|c|}
\hline B-25 Inside & & Area & Area & Volume & Corrosion & Corrosion & Year & Volume & $\begin{array}{c}\text { Corroded } \\
\text { (percent }\end{array}$ & $\begin{array}{c}\text { Total } \\
\text { Volume }\end{array}$ & $\begin{array}{l}\text { Volume } \\
\text { Reduction }\end{array}$ \\
\hline $\begin{array}{l}\text { Area/Volume } \\
\text { (sq. ft./cu. ft.) }\end{array}$ & $\begin{array}{c}\text { Type } \\
\text { Corrosion }\end{array}$ & $\begin{array}{l}\text { Impacted } \\
\text { (percent) }\end{array}$ & $\begin{array}{l}\text { Impacted } \\
\text { (sq. ft. })^{2}\end{array}$ & $\begin{array}{l}\text { Impacted } \\
\text { (cu. ft. })^{3}\end{array}$ & $\begin{array}{c}\text { Rate } \\
\left(_{(\mathrm{mils} / \mathrm{yr})^{1}}\right.\end{array}$ & $\begin{array}{c}\text { Rate } \\
(\text { cu.ft/yr) }\end{array}$ & $\begin{array}{c}\text { (since } \\
\text { disposal) }\end{array}$ & $\begin{array}{c}\text { Corroded } \\
\text { (cu. ft. })^{5}\end{array}$ & $\begin{array}{l}\text { lid/bottom/ } \\
\text { or sides) }\end{array}$ & $\begin{array}{l}\text { Reduction } \\
(\text { cu. ft })^{7}\end{array}$ & $\begin{array}{c}\text { (percent lid/ } \\
\text { bottom/or sides) }\end{array}$ \\
\hline
\end{tabular}

\section{Bottom}

$\begin{array}{llll}\text { General Corrosion } & 76 & 17.48 & 0.1593 \\ \text { General Corrosion } & 76 & 17.48 & 0.1593 \\ \text { General Corrosion } & 76 & 17.48 & 0.1593 \\ \text { General Corrosion } & 76 & 17.48 & 0.1593 \\ \text { General Corrosion } & 76 & 17.48 & 0.1593 \\ \text { General Corrosion } & 76 & 17.48 & 0.1593\end{array}$

$\begin{array}{cccc} & & & 0 \\ 0.1593 & 0.63 & 0.0009155 & 300 \\ 0.1593 & 0.63 & 0.0009155 & 314 \\ 0.1593 & 0.63 & 0.0009155 & 350 \\ 0.1593 & 0.63 & 0.0009155 & 400 \\ 0.1593 & 0.63 & 0.0009155 & 420 \\ 0.1593 & 0.63 & 0.0009155 & \mathbf{4 6 2}\end{array}$

$$
\begin{aligned}
& 0.08777 \\
& 0.09103 \\
& 0.09929 \\
& 0.11049 \\
& 0.11488 \\
& \mathbf{0 . 1 2 4 0 3}
\end{aligned}
$$

Comments:

${ }^{1}$ From Dunn (2002).

${ }^{2}$ Area impacted percent $\mathrm{x}$ total sq. $\mathrm{ft}$. area of total lid, bottom, or 4-sides.

${ }^{3}$ Area impacted (sq. ft.) $x$ thickness $(0.009116 \mathrm{ft}$.).

${ }^{4}$ Volume impacted /number of years for through-wall penetration.

${ }^{5}$ Modified Bradford equation (vol corroded cu. $\mathrm{ft}=\left(\right.$ years since disposal $\left.{ }^{0.7}\right) \times$ corrosion rate cu. $\mathrm{ft} / \mathrm{yr}$ ).

${ }^{6}$ (Volume corroded for given corrosion type/total volume) $\mathrm{x} 100$.

${ }^{7}$ Sum of the volumes of the various corrosion types.

${ }^{8}$ Total volume reduction (volume corroded)/ total lid, bottom, or 4-sides' volume. 
Table A9. Slowing Corrosion Method - Sides Percent Volume Loss Over Time

\begin{tabular}{|c|c|c|c|c|c|c|c|c|c|c|c|}
\hline $\begin{array}{l}\text { B-25 Inside } \\
\text { Area/Volume } \\
\text { (sq. ft./cu. ft.) }\end{array}$ & $\begin{array}{c}\text { Type } \\
\text { Corrosion }\end{array}$ & $\begin{array}{c}\text { Area } \\
\text { Impacted } \\
\text { (percent) }^{1}\end{array}$ & $\begin{array}{c}\text { Area } \\
\text { Impacted } \\
{\text { (sq. ft. })^{2}}^{2}\end{array}$ & $\begin{array}{l}\text { Volume } \\
\text { Impacted } \\
{\text { (cu.ft. })^{3}}\end{array}$ & $\begin{array}{l}\text { Corrosion } \\
\text { Rate } \\
\text { (mils/yr) }^{1}\end{array}$ & $\begin{array}{c}\text { Corrosion } \\
\text { Rate } \\
\text { (cu. ft/yr) } \\
\end{array}$ & $\begin{array}{c}\text { Years } \\
\text { (since } \\
\text { disposal) }\end{array}$ & $\begin{array}{l}\text { Volume } \\
\text { Corroded } \\
\underline{(\mathrm{cu} . \mathrm{ft} .)^{5}}\end{array}$ & $\begin{array}{c}\text { Volume } \\
\text { Corroded } \\
\text { (percent } \\
\text { lid/bottom/ } \\
\text { or sides) }^{6}\end{array}$ & $\begin{array}{c}\text { Total } \\
\text { Volume } \\
\text { Reduction } \\
\underline{(\mathrm{cu} . \mathrm{ft})^{7}}\end{array}$ & $\begin{array}{c}\text { Total } \\
\text { Volume } \\
\text { Reduction } \\
\text { (percent lid/ } \\
\text { bottom/or side }\end{array}$ \\
\hline & & & & & & & 0 & & & & 0 \\
\hline Sides & Scattered Pitting & 20 & 15.404 & 0.1404 & 1.3 & 0.0016714 & 42 & 0.03324 & 4.74 & 0.03324 & 5 \\
\hline$($ area $=77.02)$ & Scattered Pitting & 20 & 15.404 & 0.1404 & 1.3 & 0.0016714 & 46 & 0.03575 & 5.09 & 0.03575 & 5 \\
\hline (volume $=0.702$ cu.ft.) & Scattered Pitting & 20 & 15.404 & 0.1404 & 1.3 & 0.0016714 & 50 & 0.03822 & 5.44 & 0.03822 & 5 \\
\hline (thickness $=0.009116 \mathrm{ft})$. & Scattered Pitting & 20 & 15.404 & 0.1404 & 1.3 & 0.0016714 & 64 & 0.04656 & 6.63 & 0.04656 & 7 \\
\hline (thickness = 109.4 mils) & Scattered Pitting & 20 & 15.404 & 0.1404 & 1.3 & 0.0016714 & 84 & 0.05788 & 8.24 & 0.05788 & 8 \\
\hline & Scattered Pitting & 20 & 15.404 & 0.1404 & 1.3 & 0.0016714 & 100 & 0.06654 & 9.48 & 0.06654 & 9 \\
\hline & Scattered Pitting & 20 & 15.404 & 0.1404 & 1.3 & 0.0016714 & 150 & 0.09204 & 13.11 & 0.09204 & 13 \\
\hline & Scattered Pitting & 20 & 15.404 & 0.1404 & 1.3 & 0.0016714 & 174 & 0.10364 & 14.76 & 0.10364 & 15 \\
\hline & Scattered Pitting & 20 & 15.404 & 0.1404 & 1.3 & 0.0016714 & 200 & 0.11585 & 16.50 & 0.11585 & 17 \\
\hline & Scattered Pitting & 20 & 15.404 & 0.1404 & 1.3 & 0.0016714 & 209 & 0.12000 & 17.09 & 0.12000 & 17 \\
\hline & Scattered Pitting & 20 & 15.404 & 0.1404 & 1.3 & 0.0016714 & 237 & 0.13270 & 18.90 & 0.13270 & 19 \\
\hline & Scattered Pitting & 20 & 15.404 & 0.1404 & 1.3 & 0.0016714 & 250 & 0.13849 & 19.73 & 0.13849 & 20 \\
\hline & Scattered Pitting & 20 & 15.404 & 0.1404 & 1.3 & 0.0016714 & 300 & 0.16024 & 22.83 & 0.16024 & 23 \\
\hline & Scattered Pitting & 20 & 15.404 & 0.1404 & 1.3 & 0.0016714 & 314 & 0.16620 & 23.67 & 0.16620 & 24 \\
\hline & Scattered Pitting & 20 & 15.404 & 0.1404 & 1.3 & 0.0016714 & 350 & 0.18127 & 25.82 & 0.18127 & 26 \\
\hline & Scattered Pitting & 20 & 15.404 & 0.1404 & 1.3 & 0.0016714 & 400 & 0.20171 & 28.73 & 0.20171 & 29 \\
\hline & Scattered Pitting & 20 & 15.404 & 0.1404 & 1.3 & 0.0016714 & 420 & 0.20974 & 29.88 & 0.20974 & 30 \\
\hline & Scattered Pitting & 20 & 15.404 & 0.1404 & 1.3 & 0.0016714 & 462 & 0.22636 & 32.24 & 0.22636 & 32 \\
\hline & Scattered Pitting & 20 & 15.404 & 0.1404 & 1.3 & 0.0016714 & 500 & 0.24113 & 34.35 & 0.24113 & 34 \\
\hline & Scattered Pitting & 20 & 15.404 & 0.1404 & 1.3 & 0.0016714 & 1000 & 0.41984 & 59.81 & 0.41984 & 60 \\
\hline & Scattered Pitting & 20 & 15.404 & 0.1404 & 1.3 & 0.0016714 & 1299 & 0.51757 & 73.73 & 0.51757 & 74 \\
\hline & Scattered Pitting & 20 & 15.404 & 0.1404 & 1.3 & 0.0016714 & 1500 & 0.58070 & 82.72 & 0.58070 & 83 \\
\hline & Scattered Pitting & 20 & 15.404 & 0.1404 & 1.3 & 0.0016714 & 1592 & 0.60902 & 86.76 & 0.60902 & 87 \\
\hline & Scattered Pitting & 20 & 15.404 & 0.1404 & 1.3 & 0.0016714 & 1901 & 0.70200 & 100.00 & 0.70200 & 100 \\
\hline
\end{tabular}

